\title{
Toxin-Antitoxin Systems in Clinical Pathogens
}

\author{
Laura Fernández-García ${ }^{1}$, Lucia Blasco ${ }^{1}$, Maria Lopez ${ }^{1,2}$, German Bou 1,2, \\ Rodolfo García-Contreras $^{3}$, Thomas Wood ${ }^{4,5}$ and María Tomas 1,2,*
}

1 Servicio de Microbiología, Complejo Hospitalario Universitario A Coruña-INIBIC, A Coruña 15006, Spain; laugemis@gmail.com (L.F.-G.); lucia.blasco@gmail.com (L.B.); maria.lopez.diaz@sergas.es (M.L.); german.bou.arevalo@sergas.es (G.B.)

2 Spanish Network for Research in Infectious Diseases (REIPI), Seville 41071, Spain

3 Departamento de Microbiología y Parasitología, Facultad de Medicina, Universidad Nacional Autónoma de México, Ciudad de México 04510, México; rgarc@bq.unam.mx

4 Department of Chemical Engineering Pennsylvania State University, University Park, 16802 PA, USA; tuw14@psu.edu

5 Department of Biochemistry and Molecular Biology, Pennsylvania State University, University Park, 16802 PA, USA

* Correspondence: ma.del.mar.tomas.carmona@sergas.es; Tel.: +34-981176399; Fax: +34-981178273

Academic Editor: Anton Meinhart

Received: 9 May 2016; Accepted: 7 July 2016; Published: 20 July 2016

\begin{abstract}
Toxin-antitoxin (TA) systems are prevalent in bacteria and archaea. Although not essential for normal cell growth, TA systems are implicated in multiple cellular functions associated with survival under stress conditions. Clinical strains of bacteria are currently causing major human health problems as a result of their multidrug resistance, persistence and strong pathogenicity. Here, we present a review of the TA systems described to date and their biological role in human pathogens belonging to the ESKAPE group (Enterococcus faecium, Staphylococcus aureus, Klebsiella pneumoniae, Acinetobacter baumannii, Pseudomonas aeruginosa and Enterobacter spp.) and others of clinical relevance (Escherichia coli, Burkholderia spp., Streptococcus spp. and Mycobacterium tuberculosis). Better understanding of the mechanisms of action of TA systems will enable the development of new lines of treatment for infections caused by the above-mentioned pathogens.
\end{abstract}

Keywords: clinical; pathogens; Toxin-Antitoxin; plasmids; chromosome; resistance; persistance; virulence

\section{Introduction}

Toxin-antitoxin (TA) systems, which occur in bacteria and archaea, consist of a toxin and an antitoxin, which are respectively stable and unstable components [1,2]. Both components constitute a complex in which the toxin activity or synthesis is inhibited by an antitoxin. Under some conditions, a labile antitoxin is degraded, favoring the action of the toxin by inhibition of essential cellular processes, such as translation, replication, ATP (Adenosine triphosphate) synthesis and cell wall synthesis [2-4].

TA systems are either encoded by plasmids or reside in bacterial chromosomes [5]. TA systems in plasmids (TAp) have been associated with plasmid stabilization [6]. It has been theorized that toxin/antitoxin loci serve only to maintain plasmid DNA at the expense of the host organism [7]. Other authors propose that these systems have evolved to favor the competitive ability of plasmids in cell progeny [8]. This hypothesis has been corroborated by computer modeling [8]. However, the role of TA systems encoded by bacterial chromosomes (TAc) is much less well known [9]. Similarly to TAp, the TAc systems have been suggested to play a role in the stabilization of various genetic 
(pathogenicity islands and prophages) or stress response functions of modular elements of bacterial growth and death [10-12].

TA systems are currently classified into five groups (types I to V) according to the nature of the antitoxin and the mode of interaction between the toxin and antitoxin [13] (Figure 1). In all cases, the toxins are proteins, while the antitoxins in TA systems types I and III are RNA molecules, and those in TA systems types II, IV and V are proteins. In type I systems, the antitoxin suppresses activity of the toxin protein by binding to its mRNA, whereas in the type II and III TA systems, toxin proteins are blocked by direct binding of antitoxin proteins and the antitoxin RNA, respectively. In type IV TA systems, the antitoxin protein prevents the activity of the toxin by binding to its substrate, and finally, in type V TA systems, the antitoxin RNAse specifically degrades toxin mRNA [13,14].
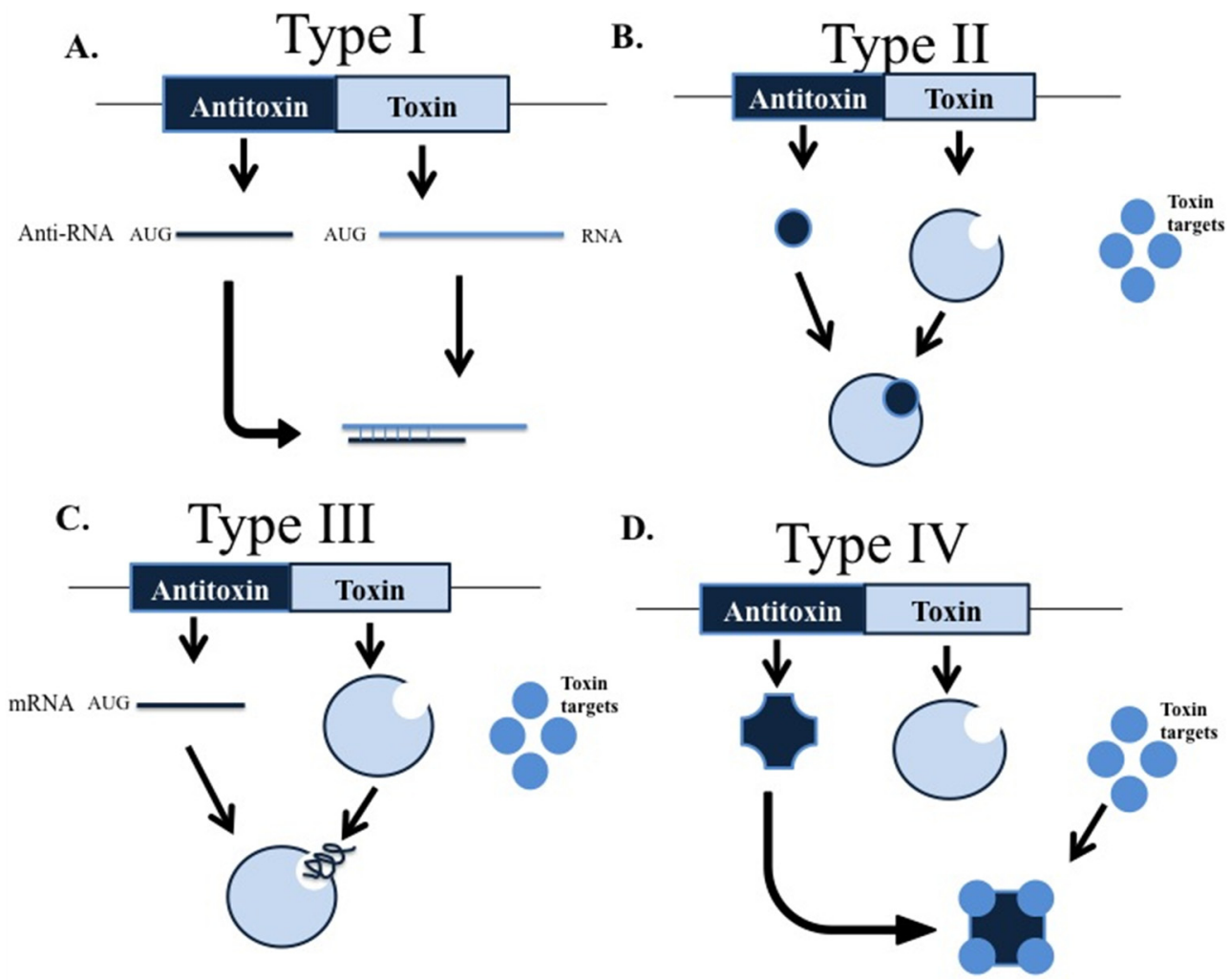

\section{E. Type V}
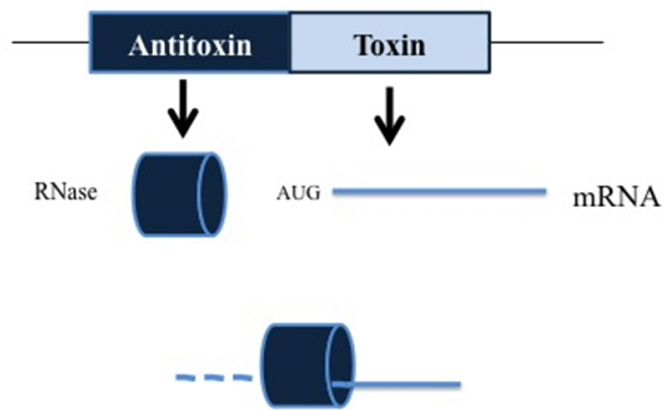

Figure 1. Models representing the interaction between toxins and antitoxins in the different types of toxin-antitoxin (TA) systems. (A) Type I: the antitoxin mRNA binding to toxin mRNA, which prevents toxin protein formation; (B) type II: a TA complex is formed by the union of toxin and antitoxin proteins; (C) type III: a TA complex is formed by the union of toxin protein with antitoxin mRNA; (D) type IV: the antitoxin protein binds to the toxin target, blocking its action; (E) type V: the antitoxin mRNA encodes an RNAse that degrades the toxin mRNA. 
Hospital-acquired infections are an important problem in the industrialized world, with reported incidence rates of 5\% in the United States (U.S.) and 7.1\% the European Union (EU) in 2013 [15]. The risk of fatality associated with infections caused by multidrug-resistant (MDR) bacteria (superbugs) is also very high [15]. In recent years, the Infectious Diseases Society of America (IDSA) has highlighted a group of antibiotic-resistant bacteria (Enterococcus faecium, Staphylococcus aureus, Klebsiella pneumoniae, Acinetobacter baumannii, Pseudomonas aeruginosa and Enterobacter spp.), acronymically labelled "the ESKAPE pathogens", which are capable of "escaping" the biocidal action of antibiotics and mutually representing new paradigms in pathogenesis, transmission and resistance [16]. Several studies have analyzed the function of TAp systems in stabilizing the plasmids that carry resistance genes in clinical pathogens. However, the role of TAc systems in the life of nosocomial bacterial pathogens (ESKAPE) is not well known. TAc systems have been associated with (i) bacterial persistence, by generating slowly-growing cells tolerant to antibiotics and environmental changes, and (ii) biofilm formation, by regulating fimbriae [17]. and by programmed cell death. Nonetheless, there is some controversy regarding the role of TA systems. In a review article, Gerdes et al. related the persistence of E. coli as a model organism to type II TA systems. More specifically, these authors suggested that the deletion of type II TA loci significantly reduced the level of persistence [18,19]. However, Kolodkin-Gal et al. studied the involvement of the MazF/MazE and the YafQ/DinJ TA systems in cell death and participation in biofilm formation through novel, as yet unknown mechanism(s) [19].

In this review, we focus on the TA systems that occur in plasmids (TAp) and chromosomes (TAc) of the nosocomial pathogens belonging to the ESKAPE group, as well as other community pathogens that are important in terms of their multi-drug resistance and virulence, i.e., Escherichia coli, Burkholderia spp., Streptococcus pneumoniae and Mycobacterium tuberculosis.

The role of toxin-antitoxin systems in clinical pathogens is shown in Table 1.

Table 1. Role of different types of TA (Toxin-antitoxin) systems in clinical pathogens. ESKAPE group (Enterococcus faecium, Staphylococcus aureus, Klebsiella pneumoniae, Acinetobacter baumannii, Pseudomonas aeruginosa and Enterobacter spp.) and other pathogens of clinical interest.

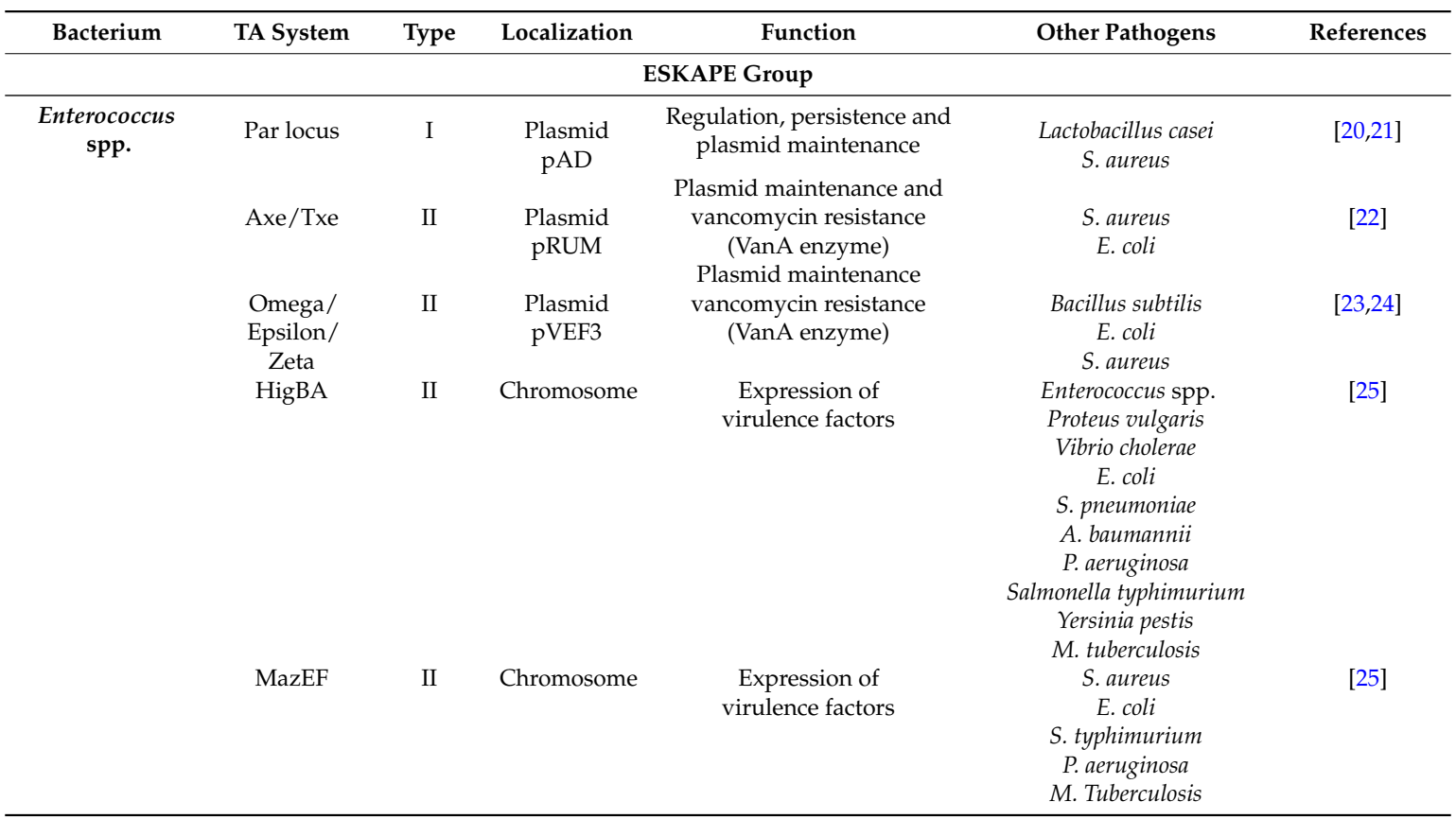


Table 1. Cont.

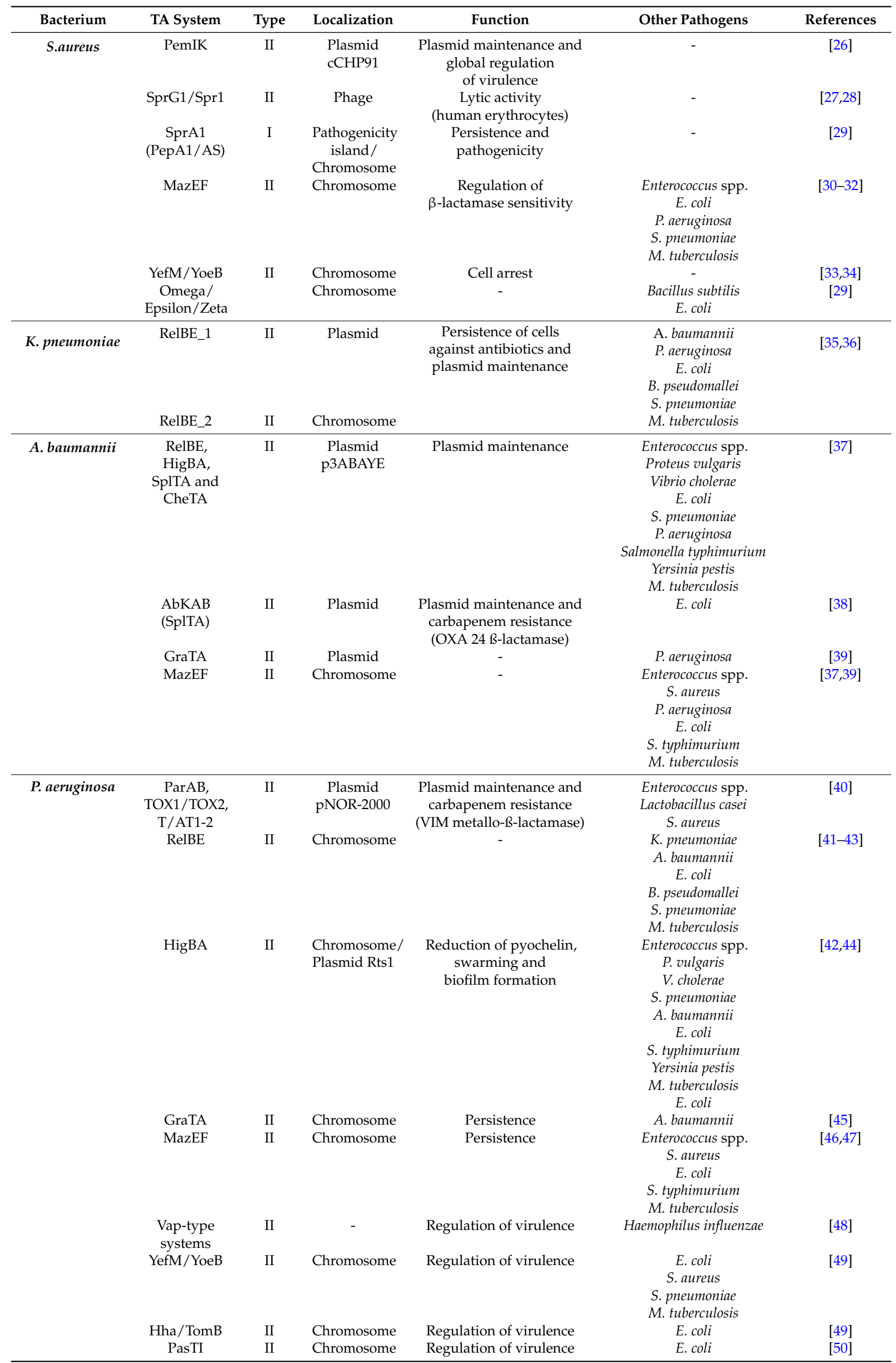


Table 1. Cont.

\begin{tabular}{|c|c|c|c|c|c|c|}
\hline Bacterium & TA System & Type & Localization & Function & Other Pathogens & References \\
\hline \multirow[t]{9}{*}{ E.coli } & $\begin{array}{c}\text { PemIK, } \\
\text { VagCD, } \\
\text { CcdAB, } \\
\text { Hok/Sok, } \\
\text { ParAB and } \\
\text { PsiAB }\end{array}$ & II & $\begin{array}{c}\text { Plasmid } \\
\text { pEC302104 }\end{array}$ & $\begin{array}{l}\text { Plasmid maintenance and } \\
\text { B-lactam resistance } \\
\text { (ESBL B-lactamase) }\end{array}$ & $\begin{array}{l}\text { Enterococcus spp. } \\
\quad \text { S. aureus }\end{array}$ & {$[51,52]$} \\
\hline & TisB/IstR & I & Chromosome & Regulation of SOS response & - & {$[4,53]$} \\
\hline & SymER & $\mathrm{I}$ & Chromosome & Regulation of SOS response & - & [54] \\
\hline & MazEF & II & Chromosome & $\begin{array}{l}\text { Persistence, } \\
\text { biofilm formation }\end{array}$ & $\begin{array}{l}\text { Enterococcus spp. } \\
\text { S. aureus } \\
\text { S. typhimurium } \\
\text { P. aeruginosa } \\
\text { M. tuberculosis }\end{array}$ & [55-58] \\
\hline & YefM/YoeB & II & Chromosome & $\begin{array}{l}\text { Persistence, } \\
\text { biofilm formation }\end{array}$ & $\begin{array}{l}\text { S. aureus, } \\
\text { P. aeruginosa } \\
\text { S. pneumoniae }\end{array}$ & {$[60]$} \\
\hline & MqsRA & II & Chromosome & $\begin{array}{l}\text { Influence on biofilm } \\
\text { formation and global stress } \\
\text { response. Control of GhoTS } \\
\text { System. Increased tolerance } \\
\text { to bile acid. }\end{array}$ & - & {$[49-61]$} \\
\hline & GhoTS & $\mathrm{V}$ & Chromosome & $\begin{array}{c}\text { Persistence, } \\
\text { biofilm formation }\end{array}$ & - & {$[49,62]$} \\
\hline & Hha/TomB & II & Chromosome & $\begin{array}{c}\text { Persistence, decreases } \\
\text { biofilm formation by } \\
\text { inhibiting fimbriae } \\
\text { production. }\end{array}$ & P. aeruginosa & {$[49,61]$} \\
\hline & PasTI & II & - & Persistence & P. aeruginosa & {$[50]$} \\
\hline \multirow[t]{3}{*}{$\begin{array}{l}\text { Burkholderia } \\
\text { spp. }\end{array}$} & TAS1/TAS2 & II & Plasmid pC3 & $\begin{array}{l}\text { Plasmid maintenance and } \\
\text { tolerance to antibiotics }\end{array}$ & -5 & {$[63,64]$} \\
\hline & RelBE & II & Chromosome & Persistence & $\begin{array}{c}\text { K. pneumoniae } \\
\text { A. baumannii } \\
\text { P. aeruginosa } \\
\text { E. coli } \\
\text { S. pneumoniae } \\
\text { M. tuberculosis }\end{array}$ & [63] \\
\hline & Hic AB & II & Chromosome & Persistence & E. coli & {$[64,65]$} \\
\hline \multirow[t]{4}{*}{$\begin{array}{l}\text { Streptococcus } \\
\text { spp. }\end{array}$} & YefM/YoeB & II & - & $\begin{array}{l}\text { Implicated in pathogenicity, } \\
\text { phase variation, } \\
\text { genetic competence, } \\
\text { biofilm formation } \\
\text { and bistability }\end{array}$ & $\begin{array}{c}\text { E. coli } \\
\text { S. aureus } \\
\text { P. aeruginosa } \\
\text { M. tuberculosis }\end{array}$ & {$[66,67]$} \\
\hline & PezAT & II & - & $\begin{array}{c}\text { Persistence and } \\
\text { biofilm formation }\end{array}$ & - & \\
\hline & RelBE & II & Chromosome & $\begin{array}{l}\text { Associated with survival } \\
\text { and human colonization }\end{array}$ & $\begin{array}{l}\text { K. pneumoniae } \\
\text { A. baumannii } \\
\text { P. aeruginosa } \\
\text { E. coli } \\
\text { B. pseudomallei } \\
\text { M. tuberculosis }\end{array}$ & {$[66]$} \\
\hline & Phd-Doc & - & - & & - & {$[68]$} \\
\hline
\end{tabular}


Table 1. Cont.

\begin{tabular}{|c|c|c|c|c|c|c|}
\hline Bacterium & TA System & Type & Localization & Function & Other Pathogens & References \\
\hline \multirow[t]{7}{*}{ M. tuberculosis } & YefM/YoeB & II & Chromosome & Persistence & $\begin{array}{c}\text { E. coli } \\
\text { S. aureus } \\
\text { P. aeruginosa } \\
\text { S. pneumoniae }\end{array}$ & [69-71] \\
\hline & RelBE & II & Chromosome & Persistence & $\begin{array}{c}\text { K. pneumoniae } \\
\text { A. baumannii } \\
\text { P. aeruginosa } \\
\text { E. coli } \\
\text { B. pseudomallei } \\
\text { S. pneumoniae }\end{array}$ & {$[70,71]$} \\
\hline & ParDE & II & Chromosome & Persistence & - & [72] \\
\hline & HigBA & II & Chromosome & Persistence & $\begin{array}{c}\text { Enterococcus spp. } \\
\text { P. vulgaris } \\
\text { V. cholerae } \\
\text { A. baumannii } \\
\text { E. coli } \\
\text { S. pneumoniae } \\
\text { Salmonella typhimurium } \\
\text { Yersinia pestis }\end{array}$ & {$[73,74]$} \\
\hline & TAC & & Chromosome & - & - & [69] \\
\hline & MazEF & II & Chromosome & Persistence and cell arrest & $\begin{array}{l}\text { Enterococcus spp. } \\
\text { S. aureus } \\
\text { E. coli } \\
\text { S. typhimurium } \\
\text { P. aeruginosa }\end{array}$ & [75] \\
\hline & VapBC & II & Chromosome & Persistence & $\begin{array}{l}\text { P. aeruginosa } \\
\text { H. influenzae }\end{array}$ & {$[17,76,77]$} \\
\hline
\end{tabular}

\subsection{Pathogens in the ESKAPE Group}

\subsubsection{Enterococcus spp.}

Enterococcus faecalis and E. faecium (order Lactobacillus) are well-known nosocomial pathogens that cause hospital bacteremia, urinary tract infections and surgical wound infections. Enterococci are intrinsically resistant to different antibiotics and can also acquire other types of resistance via mobile genetic elements [78].

Several TAp systems associated with plasmid maintenance have been described in this pathogen. The $\operatorname{Par}_{\mathrm{Ef}}$ locus of the E. faecalis plasmid pAD1 is an RNA-regulated addiction module encoding the Fst peptide toxin. This locus has also been found in other bacteria, such as Lactobacillus casei and S. aureus [20]. In addition, five genes encoding Fst homologues in E. faecalis plasmids have been identified [79]. In 2006, Patel et al. confirmed the role of the Fst toxin in E. faecalis strains affecting chromosomal segregation and cell division/peptidoglycan synthesis [21]. The target of this protein is probably located at or near the cell membrane, due to the presence of a hydrophobic stretch of amino acids predicted to form a trans-membrane domain. However, this target either only affects DNA segregation directly or affects both DNA segregation and cell division, and this must be clarified [21]. The omega/epsilon/zeta TAp module has been characterized in plasmid (TAp) and chromosome (TAc) TA systems in pVEF3 plasmids from E. faecium resistant to vancomycin (carrying VanA) and persisting on Norwegian poultry farms [23]. The pRUM plasmid encodes multidrug-resistant genes (van genes) in E. faecium. Bioinformatic analysis of the pRUM sequence enabled identification of a new TAp protein module (Axe/Txe), which is found in multiple bacteria genomes [80]. Co-hybridization studies showed that $90 \%$ of the clinical isolates of E. faecium were PCR-positive for the pRUM and Axe/Txe TAp systems [22]. The study findings also suggested a genetic relationship between the pRUM replicon and axe/txe TAp genes [22]. The axe-txe plasmid system has two promoters, the main one of which has been found upstream of an antitoxin gene and is cooperatively regulated by the TA complex. The second was found embedded in the antitoxin CDS and may act in regulating the TA ratio and in modulating toxin transcript stability [81]. The presence of vancomycin resistance has been found to be related to the presence of axe/txe TAp genes [22]. Finally, Torill and collaborators [24] investigated the presence of the omega/epsilon/zeta $\mathrm{Ef}$ and Axe/Txe TAp systems in relation to the 
VanA protein, observing that the Axe-Txe TAp system intervenes in maintaining plasmid stability in E. faecium and that the omega/epsilon/zeta $\mathrm{Ef}$ TAp system stabilizes the plasmid in Bacillus subtilis, E. coli, E. faecium and E. faecalis. These researchers described the high prevalence of TA operons in vancomycin-resistant Enterococcus isolates (VRE) relative to sensitive isolates, and their conclusions are consistent with the findings of other authors. The high prevalence of these systems has been related to their role in stable inheritance of the plasmid pool and the relatively large number of VRE plasmids [24].

The Tac systems HigBA $\mathrm{Ef}_{\text {and }}$ and $\mathrm{MazF}_{\mathrm{Ef}}$ have been located in the chromosome of E. faecalis and E. faecium clinical strains and found to be associated with the expression of virulence factors [25].

\subsubsection{Staphylococcus aureus}

Staphylococcus aureus is a Gram-positive bacterium (order Bacillales) responsible for an increasing number of nosocomial and community acquired infections. The adaptability of this bacterium to environmental changes, involving temperature, nutritional deprivation or the presence of antibiotics, depends on two component systems: transcription regulatory proteins and regulatory RNAs [29,30].

Until now, only one TAp system has been described in the CCHP91 plasmid in S. aureus PeImK ${ }_{\mathrm{Sa}}$. This system comprises a toxin, PemK $\mathrm{Sa}_{\mathrm{a}}$, which is a specific ribonuclease for the UAUU sequence, and an antitoxin, PemI $I_{\mathrm{Sa}}$, which inhibits the toxin by physical interaction. This system is implicated in the maintenance of the plasmid and probably in the regulation of virulence via alteration of the translation of a large pool of genes [26].

SrpG1, which belongs to the TxpA-RatA family (type II TA system), is encoded in the mobile genetic element $\Phi$ Sa3 PI (phage) in S. aureus strain N315. The srpG1 gene overlaps with the SrpF1 non-coding RNA antitoxin. The RNA is constitutively expressed. SrpG1 is negatively regulated by a duplex formation with SrpF1, probably by RNA degradation (Figure 2). Two peptides of different sizes are encoded by SrpG1, yielding a 44-amino acid peptide from the first AUG start codon and, more abundantly, a 31 amino acid peptide from an internal AUG codon. Both peptides are secreted by pore-forming toxins displaying activity against Gram-positive and Gram-negative bacteria, and the longer peptide displays a higher level of lytic activity against human erythrocytes $[27,28]$.

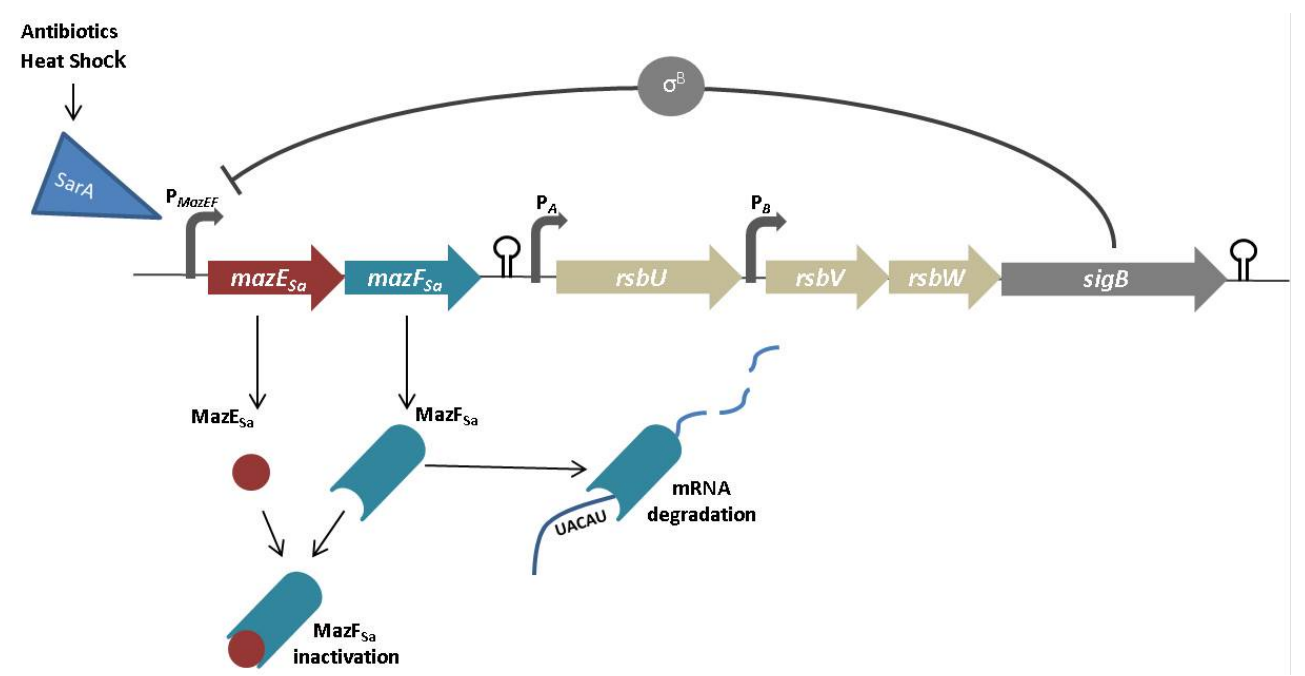

Figure 2. Model of MazEFSa regulation. Transcription of the operon mazES-rsbUVW-sigB is initiated by the mazEF promoter, and transcription of the rsbUVW-sigB genes depends on the activity of the transcriptional terminator downstream of the mazE and mazF genes. This system is negatively regulated by the $\sigma \mathrm{B}$, encoded by sigB, which represses the mazEF promoter. Toxin MazF is an RNAse that degrades the mRNA in the UACAU site. The antitoxin MazE binds and inactivates the toxin MazF. This system is negatively regulated by the $\sigma \mathrm{B}$ encoded by sigB. 
Several TAc systems are located in S. aureus strains. In 2012, Sayed and co-workers [29] reported the existence in $S$. aureus of a functional type I TA system previously predicted by computer modelling [82]. This system is located within a pathogenicity island and consists of the SprA1 toxin peptide (PepA1) and SprA1 (AS) RNA antitoxin. PepA1 is induced by oxidative and acidic stress during cell growth and is repressed by an antitoxin type I RNA, the SprAsa antitoxin. Two explanations for why PepA1 is induced by oxidative and acidic stress have been proposed: one is that under such conditions PepA1 is induced in most of the rapidly dividing internalized bacteria, and slowly dividing bacteria can thus persist and escape the phagolysosomes, the membranes of which will also be damaged by PepA1. Another hypothesis proposes that under oxidative or acidic stress, PepA1 can modulate the activity of membrane proteins involved in iron transport, which together with its hemolytic activity will drive the lysis of the host erythrocytes during infection under iron-limited conditions [29]. The type II TAc systems identified in S. aureus are MazEF $F_{\mathrm{Sa}}, \mathrm{YefM} / \mathrm{YoeB}$ and $\mathrm{PemlK}_{\mathrm{Sa}}$. $\mathrm{MazEF}_{\mathrm{Sa}}$ encodes the MazE $\mathrm{Sa}_{\mathrm{S}}$ antitoxin and the $\mathrm{MazF}_{\mathrm{Sa}}$ RNAse toxin $[31,83]$. In an in vivo study of S. aureus, Fu and coworkers [32]. identified other cleavage sites in spa, sigB and hla mRNAs. It has recently been demonstrated that the $s p a$ and $r s b W$ transcripts are cleaved by the RNAse MazF in the same UACAU recognition sequence. In S. aureus, in contrast to the classic TA systems, $\mathrm{MazF}_{\mathrm{Sa}}$ activity was observed with no changes in the toxin-antitoxin ratio at high levels of toxin, and $\mathrm{MazF}_{\mathrm{Sa}}$ cleavage was observed in both the presence and absence of MazE. In S. aureus, MazEF $F_{S a}$ is located upstream of the $\operatorname{sig} B$ locus encoding the alternative sigma factor $\sigma^{\mathrm{B}}$, and the adjacent locus encoding another anti-sigma factor $r s b U V W$ is implicated in the ability of the bacterium to survive under adverse conditions and in its ability to redirect the RNA polymerase to the transcription of genes involved in the stress response. $\sigma^{\mathrm{B}}$ also plays a role in the expression of virulence genes. This operon, composed by mazES-rsbUVW-sigB, is regulated by three promoters. Unlike other TAc systems, MazEF $\mathrm{Sa}_{\mathrm{a}}$ is not self-regulated, as in this case, the PmazEF promoter is activated by the SarA regulator and is induced by heat shock or antibiotic stress. In addition, both promoters are upstream $r s b U$ and the $r s b V$ genes, and two transcriptional terminators are present downstream of the $m a z E F_{S a}$ genes and the $\operatorname{sig} B$ gene [28]. This promoter is also negatively regulated by SigB, which acts as a feedback loop for repression of its own transcription $[30,32]$. Altered sensitivity to $\beta$-lactams was observed in a $\Delta m a z E F_{\mathrm{Sa}}$ strain, thus suggesting a specific regulatory role for the $\mathrm{MazEF}_{\mathrm{Sa}}$ locus in $\beta$-lactams sensitivity [31]. A second type I TAc system present in $S$. aureus comprises two operons, yefM/yoe $B_{S a 1}$ and yefM/yoe $B_{S a 2}$ (previously identified as axe1-txe1 and axe2-txe2), which are homologous to the YefM/YoeB $\mathrm{Ec}_{\mathrm{Ec}}$ system in E. coli. Like $Y_{o e} B_{\mathrm{Ec}}$, both $\mathrm{YoeB}_{\mathrm{Sa} 1}$ and $\mathrm{YoeB}_{\mathrm{Sa} 2}$ exhibit cellular RNAse activity by inhibiting the initiation of translation and arresting cellular growth [33,34]. Finally, the third system is the omega/epsilon/zetasa system (type II TAc system), a three-component system with a characteristic organization. This system has been located in the multidrug resistance streptococcal plasmid pSM19035 that was chromosomally integrated in the CM05 strain [84]. In this system, the zeta component is the toxin and is inhibited by the antitoxin, the epsilon component, and the operon is regulated by the third component, omega. A 7-bp repeat binding site was identified upstream of the omega site, thus suggesting autoregulation of the operon [24,84]. Additionally, the product of the omega gene can participate in partitioning of the plasmid as the ParB protein [85]. Although the function of this system in S. aureus is not clear, a role in plasmid stabilization in Enterococcus spp. has been demonstrated, as previously discussed [24]. A similar system was studied in Streptococcus pneumoniae, the PezAT system, in which the toxin phosphorylates the peptidoglycan precursor UDP-N-acetylglucosamine [86].

\subsubsection{Klebsiella pneumoniae}

Klebsiella pneumoniae (order Enterobacteriales) is an important opportunistic pathogen. It is found in the environment, as well as in water or solids and on plant surfaces. Due to increasing levels of antibiotic resistance, this species has become a serious threat to public health throughout the world, causing urinary tract infections, nosocomial pneumonia and intra-abdominal infections. Carbapenem 
resistant isolates of K. pneumoniae were previously associated with numerous infections with few treatment options. The genome of K. pneumoniae is extremely plastic [35].

Wei et al. [35] used a bioinformatic approach to analyze the type II TA locus distribution and compared TA diversity in 10 completely-sequenced K. pneumoniae genomes. These authors found 212 putative type II TA loci in the K. pneumoniae strains. They also showed that some RelBE-like TA groups were distributed differently from the other RelBE systems in K. pneumoniae. The RelBE_1 and RelBE_2 $\mathrm{Kp}$ loci were found in the same K. pneumoniae isolates, but were distributed differently in plasmids and chromosomes. All members of the RelBE_1 $1_{\mathrm{Kp}}$ group are found in plasmids, while all members of the RelBE_2Kp group are present in chromosomes [35]. The RelBE $E_{K p}$ system has been related to persister cells that are tolerant of antibiotics, such as $\beta$-lactams, quinolones and aminoglycosides; more persister cells appeared at high cell densities than at low cell densities [36].

\subsubsection{Acinetobacter baumannii}

Acinetobacter baumannii (order Pseudomonadales) is an important pathogen that causes nosocomial infections associated with several types of infections, including pneumonia, meningitis, septicemia and urinary tract infections [87]. Mortality in patients suffering A. baumannii infections can be as high as $75 \%$ [88]. Several factors have been associated with the pathogenesis of this bacterium: antibiotic resistance, virulence and persistence [89].

Jurenaite et al. [90] used bioinformatics tools to detect the presence of the putative TA loci in A. baumannii strains and found at least five functional TA systems. The TA systems differ in their location and abundance and are clearly associated with plasmids. The most commonly-occurring plasmid in TAp systems in A. baumannii is plasmid p3ABAYE, of a size of $94 \mathrm{~kb}$, possibly containing five TAp systems. Three of these, RelB/RelE $\mathrm{Ab}_{\mathrm{b}}$ and two versions of $\mathrm{HigB} / \mathrm{HigA} \mathrm{Ab}_{\mathrm{b}}$, are arranged in opposite directions. The other two are the so-far-unique SplTA (DUF497/COG3514 domain proteins) and CheTA (HTH/GNAT domain proteins) TA systems. In a collection of $A$. baumannii clinical isolates from Lithuanian hospitals (88.6\% prevalence among 476 clinical isolates), two of the most abundant TA systems found were the HigB/HigA $\mathrm{Ab}_{\mathrm{Ab}}$ and SplTA TA systems, which according to the results of the bioinformatic analysis are only plasmid borne. These noncanonical TA systems are the most prevalent in clinical A. baumannii isolates belonging to the ECI and ECII lineages, which are spread throughout the world. Interestingly, expression of the HigBA $\mathrm{Ab}$ TA system was not revealed by RT-PCR in 46 A. baumannii clinical strains [37]. However, Mosqueda et al. [38] located the AbkB/AbkA TA system (so-called SplTA) in the most prevalent plasmid carrying OXA 24/40 B-lactamase (main mechanism of resistance of carbapenems in A. baumannii clinical strains). The AbkB (or SplT) toxin was shown to inhibit translation when overexpressed in E. coli with cleavage of lpp mRNA and the transfer of messenger RNA (tmRNA), thus indicating that the AbkB toxin probably functions as an endoribonuclease. The presence of a TA system in these plasmids would explain their stability in the absence of any apparent selection pressure, particularly for small plasmids without the $b l a_{\mathrm{OXA} 24} / b l a_{\mathrm{OXA} 40}-$ like gene, such as pAC30a and pAC29a [91].

Interestingly, in a study of the levels of expression of the TAc type II systems in 85 A. baumannii clinical isolates, overexpression of the $\operatorname{mazEF}_{\mathrm{Ab}}$ system was observed in all chromosomal DNA. However, RelBE $\mathrm{Ab}_{\mathrm{b}}$ and $\mathrm{HigAB} \mathrm{Ab}_{\mathrm{Ab}}$ systems showed levels of expression of $88.2 \%$ and $4.7 \%$, respectively [37].

\subsubsection{Pseudomonas aeruginosa}

Pseudomonas aeruginosa (order Pseudomonadales) is an opportunistic Gram-negative pathogen [92] that causes many chronic infections, including those associated with cystic fibrosis (CF) [93], burn wound infections, bacterial keratitis, urinary infections and peritoneal dialysis catheter infections [92]. Although TA systems are important for infection, few studies have investigated the role of TA systems in pseudomonads, as TA systems have primarily been studied in E. coli [93]. This is surprising given 
that P. aeruginosa is the primary model for biofilm formation [94] and that persister cells are prevalent in biofilms, including P. aeruginosa biofilms [95].

Three Tap systems (ParAB $\mathrm{Pa}_{\mathrm{Pa}}$ TOX1/TOX2 and T/AT1-2) were identified but not characterized in 2013, in the pNOR-2000 plasmid encoding blaVIM-2, which produces resistance to carbapenems in P. aeruginosa clinical strains [40]. The other TA systems described in P. aeruginosa clinical strains are located in the chromosome. The presence of TAc systems in the Pseudomonas genus was first reported by Williams et al. [40], who showed that the genes for the type II TA systems RelE/RelB $\mathrm{Pa}_{\mathrm{Pa}}$ and $\mathrm{HigB} / \mathrm{Hig} \mathrm{A}_{\mathrm{Pa}}$ were present in 42 clinical isolates of $P$. aeruginosa; however, although the authors showed that many of these loci are transcribed, no TA system was verified. The first TA system characterized in pseudomonads was the GraT/GraA TAc system of P. putida. This type II TAc is primarily used at low temperatures [41]; the GraT toxin inhibits ribosome assembly at low temperatures by interacting with the DnaK chaperone [45]. The first TA system to be characterized in P. aeruginosa was recently reported: the HigB/HigA $A_{P a}$ type II TA system [44]. This TAc system is found in many pathogens; for example, genes for the HigB/HigA-like TA system are found in the Rts1 plasmid of Proteus vulgaris and in chromosomes of the pathogens Vibrio cholera [96,97], Streptococcus pneumoniae [98], A. baumannii [90], Salmonella typhimurium [99], Yersinia pestis [100], Mycobacterium tuberculosis [101], E. coli CFT073 [102] and E. coli $\mathrm{O} 157: \mathrm{H7}$ [103] and the system is also present in E. coli $\mathrm{K} 12$ [104]. As noted above, HigBA $\mathrm{Pa}$ is also prevalent in P. aeruginosa clinical isolates [43]. HigB is an endoribonuclease in Proteus spp. [104], $V$. cholera [96], A. baumannii [90] and E. coli K12 [103]. In P. aeruginosa, the HigB toxin is also an endoribonuclease, and the chromosomal $\mathrm{HigB} / \mathrm{HigA} \mathrm{Pa}_{\mathrm{Pa}}$ system was found to be a bona fide type II TA system as the antitoxin $\mathrm{HigB}$ was shown to mask the toxicity of HigA as a protein and both associated proteins [44]. Critically, the $\mathrm{HigB} / \mathrm{Hig} \mathrm{A}_{\mathrm{Pa}}$ system affects the virulence factors of $P$. aeruginosa, as activation of the HigB toxin reduces pyocyanin (a toxin produced and secreted by P. aeruginosa), the siderophore pyochelin, surface motility (swarming) and biofilm formation [44]. The reduction in pyochelin was also corroborated by a whole-transcriptome study [44]. The HigB/HigAPa TAc system of $P$. aeruginosa therefore affects the pathogenicity of this strain in a way that has not previously been demonstrated for other TA systems.

Many of the long-term infections produced by P. aeruginosa, such as in CF, are due to persister cells [105]. Persister cells are dormant cells [106] that arise without a genetic change in response to stress [107]. Resistant cells grow in the presence of stress factors (such as antibiotics) due to mutations, whereas persisters do not grow and are not affected, due to their metabolic inactivity. Critically, cells become persisters by means of TAc systems [108]; TAc systems cause dormancy by inactivating key metabolic functions, such as protein and ATP production [109]. The link between TAc systems and persister cells was first found through transcriptomics $[110,111]$ and later by deleting single TA systems and showing that this decreases persistence $[46,47]$.

\subsubsection{Enterobacter spp.}

We did not find any studies of TA systems in this pathogen.

\subsection{Other Pathogens}

\subsubsection{Escherichia coli}

Escherichia coli (order Enterobacteriales) is an intestinal-dwelling bacterium and an opportunistic pathogen. However, some types can cause illness and diarrhea. Moreover, a strain of E. coli called 0157: H7 causes bloody diarrhea and can sometimes cause kidney failure and even death, especially in children and adults with weakened immune systems. The first outbreak of E. coli O157: H7, identified in 1982, was associated with eating hamburger meat contaminated with the bacteria [112]. Since then, outbreaks of E. coli O157: H7 have been associated with other types of food, such as spinach, lettuce, cabbage and cucumber. 
Extended-spectrum beta-lactamase (ESBL)-plasmid encoded ESBL-enzymes, such as CTX-M and TEM, are frequently produced by E. coli strains. The following TAp systems are associated with the stabilization of these plasmids (mainly type II): Hok/Sok ${ }_{\mathrm{Ec}}, \mathrm{SrnBC}, \mathrm{VagCD} \mathrm{Ec}_{\mathrm{E}}, \mathrm{PemIK}_{\mathrm{Ec}}, \operatorname{RelBE}_{\mathrm{Ec}}$, $\mathrm{VapBC}_{\mathrm{Ec}}, \mathrm{CcdAB}, \mathrm{MazEF}_{\mathrm{Ec}}, \operatorname{ParAB}_{\mathrm{Ec}}$ and PsiAB [51,52].

At least 30 TAc systems are encoded in the E. coli K12 genome (chromosome), of which some 12 are well characterized [2]. To date, TA systems of this bacterium are arguably the best characterized and represent current paradigms. Of the five TA types, E. coli possesses the type I, II, IV and V systems. Examples of type I TA systems in E. coli include the TisB-IstR-1 pair, in which the tisB toxin gene is repressed by LexA, so that its expression is de-repressed by DNA damage as part of the SOS response. Under such conditions, enhanced tisB mRNA synthesis out-titrates IstR-1, and tisB RNA is therefore translated and toxin produced, thus decreasing the growth rate and allowing DNA repair mechanisms to act. When conditions return to normal, LexA represses tisB, and the remaining mRNA is rapidly inactivated by IsrR-1 [53]. The TisB toxin acts by destabilizing the inner membrane, probably forming a pore that dissipates the membrane potential, thus inhibiting ATP synthesis [4]. The decrease in ATP concentration then produces an abrupt decrease in transcription and translation rates, and cell replication finally ceases [4]. Another representative example of type I TA systems in E. coli is the SymE/SymR pair. As in the case of the tisB gene, the symE gene encoding the toxin is strongly repressed by LexA, antagonized by the SymR RNA and cleaved by the Lon protease; however, unlike TisB, SymE appears to act as an RNA endonuclease that helps bacteria to get rid of damaged RNA that otherwise could accumulate under SOS activating conditions, rather than acting as a pore forming toxin [54]. Examples of type II TA systems in E. coli include the MazE/MazF $\mathrm{Ec}_{\mathrm{Ec}}$ pair, in which MazF is a toxin with sequence-specific mRNA endoribonuclease activity, and the MazF concentration rises as a consequence of diverse types of stress, such as nutrient starvation, oxidative stress, high temperatures and the presence of bacteriophages $[55,56,113]$. MazF inhibits translation by cleaving mRNAs at specific sites in a ribosome-independent manner [57,58]. For the type II RelB/RelE Ec pair, the toxin RelE also degrades mRNA at specific sequences; however, in contrast to MazF, it targets RNA when it is bound to the ribosomal A site [59]. Other type II systems in E. coli include the YefM/YoeB Ec pair, in which the toxin YoeB (an analogue of RelE) blocks initiation of translation by binding to the $50 \mathrm{~S}$ ribosomal subunits and then interacts with the A site, promoting the release of the $3^{\prime}$-end portion of the mRNA from the ribosomes [60] and the MqsR/MqsA pair. Interestingly, the mqsR gene is the most highly upregulated in E. coli persister cells [110] and is also the first TA system associated with biofilms [114]. Furthermore, deletion of $m q s R$ provided the first demonstration that a single toxin could be deleted and the number of persister cells reduced, thus linking toxins to persistence [46]. The MqsR tridimensional structure consists of an alpha/beta fold that is homologous with the RelE/YoeB toxins, while MqsA is an elongated dimer that neutralizes MqsR toxicity [115]. In addition to its role as a classic antitoxin, MqsA also works as a global regulator and is the first antitoxin shown to regulate more than its own locus by binding palindromic sequences at other positions on the chromosome [116]. MqsA influences important physiological processes, such as biofilm formation and the global stress response [61]. Interestingly, the MqsR/MqsA TAc system also controls the expression of another toxin/antitoxin system, GhoT/GhoS, as MqsR preferentially cleaves the mRNA of antitoxin GhoS; hence, there is a hierarchy in TA systems as they regulate cell physiology [117]. The GhoT toxin in turn promotes the generation of cell membrane damage that decreases the production of ATP-halting metabolism, thus protecting cells during stress events [62]. One of the possible physiological roles of the MqsR/MqsA pair is to increase bacterial survival in response to the stress produced by bile acid in the gastrointestinal track, as MqsR degrades ygiS mRNA, which encodes a periplasmic protein that promotes the uptake of one of the main components of bile, the deoxycholate salt. Degradation of ygiS mRNA will then decrease the YgiS protein levels and thus decrease the uptake of deoxycholate and increase tolerance to exposure [118]. Another type II TA pair that regulates biofilm formation is Hha-TomB. The Hha toxin decreases biofilm formation by binding the promoters and repressing transcription of the rare codon tRNAs argU, ileX, ileY and proL, as these codons are over-represented 
in fimbrial genes. Fimbriae production is inhibited by an Hha-mediated decrease in tRNA, leading to decreased biofilm formation. Repression of the transcription of rare codon tRNAs by tha also promotes cell lysis and biofilm dispersal due to activation of several prophage lytic genes, such as rzpD, yfjZ, appY and alpA, and due to the induction of ClpP/ClpX proteases that activate toxins by degrading several antitoxins [49]. TA pairs are therefore among the most important regulators of E. coli physiology, influencing biofilm formation [49,61], stress response [61,113], quorum sensing [119], bacterial persistence $[108,110]$, survival in their natural habitats [118] and perhaps even virulence of pathogenic strains as in the related bacterium Salmonella [99]. The scarce, but valuable evidence for a link between TA and virulence in pathogenic $E$. coli strains is summarized in the following paragraph. Although to date there is a lack of studies characterizing TAc functions in E. coli pathogenic strains, in 2010 Fozo and coworkers [82] reported that for enterohemorrhagic E. coli (EHEC), which is the most common E. coli strain producing disease in the U.S., there are at least 26 TA pairs belonging to six distinct TA families. The same authors demonstrated experimentally that two previously uncharacterized putative toxin genes, z3289 and z3290, which occur in a region present in several E. coli and Shigella strains, but absent in the genome of the laboratory strain E. coli MG1655, are indeed able to halt growth of $E$. coli when overexpressed. Although studies evaluating the role of TA pairs in pathogenic E. coli virulence are scarce, in 2012, Norton and Mulvey [50] demonstrated, using a murine infection model, that in the uropathogenic isolate CFT073, the TA YefM-YoeB $\mathrm{Ec}_{\mathrm{Ec}}$ and YbaJ-Hha pairs are key to virulence, as mutants lacking these systems were outcompeted by the parental strain during bladder colonization. Moreover, in the same study, it was demonstrated that the PasT/PasI TAc pair aids bacterial survival in the kidneys and also increases the formation of persister cells and increases survival during oxidative and nitrosative stress. The study findings suggest that the same or other TA systems found in pathogenic E. coli strains may indeed influence virulence and survival within the host during infection and therefore warrant further research.

\subsubsection{Burkholderia spp.}

The B. cepacia complex (order Burkholderiales) is a group of 18 closely-related bacterial species that can cause severe lung infections in cystic fibrosis patients (Burkholderia cenocepacia) and melioidosis (Burkholderia pseudomallei) [120,121]. Despite antibiotic treatment, melioidosis leads to more than $44 \%$ mortality in endemic areas, and in the northeast of Thailand, it is the third most frequent cause of death due to infectious diseases. The bacterium is considered to be a potential bioterrorism agent, because it has the ability to infect by air [122].

Agnoli et al. [123] discovered a pC3 plasmid in Burkholderia cenocepacia with two putative Tap systems, TAS1 and TAS2, showing homology to the VapBC and HicAB families, respectively. These systems are associated with the stabilization of the $\mathrm{pC} 3$ under oxidative, osmotic, high-temperature and chlorhexidine-induced stress.

Moreover, several TAc modules have been associated with the tolerance of B. cenocepacia to multiple antibiotics (development of persister cells), and different type II TA modules have been detected in this bacterium [63].

Eight candidate TAc systems have been located in the genome of B. pseudomallei, and five occurred in a genomic island. Of the candidate toxins, BPSL0175 (RelE1 ${ }_{\mathrm{Bp}}$ ) and BPSS1060 (RelE2 $2_{\mathrm{Bp}}$ ) halted growth when expressed in E. coli, whereas expression of BPSS0390 (Hic $\mathrm{Bp}_{\mathrm{Bp}}$ ) or BPSS1584 (Hip $\left.\mathrm{A}_{\mathrm{Bp}}\right)$ (in an E. coli DhipBA background) caused a reduction in the number of culturable bacteria [63]. The Hic $\mathrm{AB}_{\mathrm{Bp}}$ system in this pathogen (homologous to $E$. coli) is associated with bacterial persistence, suggesting that these TAc systems may play a role in human infections [64].

\subsubsection{Streptococcus pneumoniae}

Streptococcus pneumoniae (order Lactobacillus) is a pathogen that can cause various infections in humans and severe invasive processes. This almost exclusively human pathogen causes a large number of infections (pneumonia, sinusitis, peritonitis, etc.) and severe invasive processes (meningitis, 
sepsis, etc.), particularly in the elderly, children and immunocompromised individuals. It is the main causative organism of community-acquired pneumonia [65].

Nieto et al. [124] characterized and carried out functional analysis of the YefM-YoeB $B_{S p n}$ TAc system in Streptococcus pneumoniae. The mechanism of regulation of this YefM-YoeB $\mathrm{S}_{\mathrm{Spn}} \mathrm{TA}$ system was analyzed four years later [66]. Moreover, in S. pneumoniae, this TAc system was implicated in pathogenicity, competence, biofilm formation, persistence and an interesting phenomenon called bistability. In this phenomenon, populations of genetically-identical bacteria that grow under stress conditions will separate stochastically into two or more distinct subpopulations [68]. The PezAT TAc system has been characterized in this pathogen (homologous to the epsilon-zetaspy TA system in Streptococcus pyogenes described in plasmid pSM19035 by Behnke and collaborators) $[67,86,125,126]$. This system has been associated with the development of biofilm formation in S. pneumoniae [3]. Fozo et al. subsequently provided the first description of a type I TA system in the chromosome of Streptococcus pneumoniae [82]. The RelBE2 ${ }_{\text {spn }}$ locus was associated with the survival of S. pneumoniae and colonization of humans under unfavorable conditions [127]. Chan et al. applied bioinformatic analysis to 48 pneumococcal strains and described a fourth TA system, Phd-Doc [128].

\subsubsection{Mycobacterium tuberculosis}

Tuberculosis (TB) is one of the most important infectious disease killers worldwide. According to the World Health Organization, 9.6 million people were diagnosed with TB, and 1.5 million died from the disease in 2014 [129]. Most TA systems in this genus have been observed in pathogenic strains, suggesting that they are important in the evolution of mycobacteria and in infectious processes [11].

More than 80 TAc systems have been described in the Mycobacterium tuberculosis chromosome and have been associated with the persistence and establishment of latent infections of this bacterium [130]. Sala et al. identified the TA systems in M. tuberculosis H37Rv: most are type II TA systems; three are potentially type IV TA systems; and some have not yet been classified. The following systems have been classified: YefM/YoeB $\mathrm{Mt}_{\mathrm{Mt}}$ (one system), RelBE $\mathrm{Mt}_{\mathrm{Mt}}$ (two systems), ParDE $\mathrm{Mt}_{\mathrm{Mt}}$ (two systems), HigBA $\mathrm{A}_{\mathrm{Mt}}$ (three systems), TAC (toxin-antitoxin-chaperone) in which the chaperones are SecB-like (one system), ten $\mathrm{MazEF}_{\mathrm{Mt}}$ (10 systems) and $\mathrm{VapBC}_{\mathrm{Mt}}$ (50 systems) [69].

All of the toxins belonging to YefM/YoeB $\mathrm{Mt}_{\mathrm{Mt}}$ and RelBE $\mathrm{Mt}_{\mathrm{t}}$ in $M$. tuberculosis are upregulated in response to antibiotics, suggesting that they may affect persistence [131,132]. The ParDE2 $2_{\mathrm{Ms}}$ system is being studied by Gupta et al. who have already reported that the parE toxin inhibits bacterial growth in M. smegmatis, suggesting its role in dormancy and stress adaptation. According to these authors, the ParDE2 Ms system may be one of the most important elements in tolerance and adaptation to

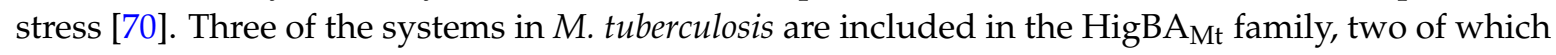
have not yet been studied in detail in mycobacteria, although researchers suspect their involvement in dormancy $[133,134]$. The $\mathrm{TAC}_{\mathrm{Mt}}$ system is regulated by the interaction between chaperone and antitoxin, thus preventing degradation of the chaperone. This system has been demonstrated to be highly conserved in the M. tuberculosis complex, suggesting an important function, in accordance with the increased activity in response to DNA damage, heat shock, nutrient starvation, hypoxia, drug-persistence and host phagocytes [71,73]. The second family system with most members in M. tuberculosis is MazEF $\mathrm{Mt}_{\mathrm{t}}$. Toxins of this family have been shown to have different targets, suggesting multiple responses: e.g., MazF6 toxins have the capacity to act on ribosomal RNA by cleaving $23 \mathrm{~S}$ rRNA of dissociated ribosomes, which leads to general inhibition of protein synthesis [73]; the MazF4 toxin interacts with DNA topoisomerase I, thus inhibiting growth [74]. It has also been demonstrated that this system may interact with other bacterial systems, e.g., the MazF9 toxin can be neutralized by antitoxins from the VapBC system, which may be explained by the low percentage of conservation between antitoxins of this system [135]. Most TA systems in M. tuberculosis belong to the VapBC family. This group is characterized by a PIN domain, which is present in the toxin component; the PIN domain is homologous to the type IV pili N-terminal domain [136]. These systems produce a response to stress conditions, such as hypoxia (systems 15, 7 and 25) and the presence of macrophage enzymes 
(systems 11, 3 and 47), supporting the idea that these systems play a role in persistence [69]. Lee et al. demonstrated that one of these enzymes, VapC30, uses magnesium as a cofactor to its ribonuclease activity in inhibiting cellular growth [136]. Some authors also suggest its involvement in the first steps of latent infection [137].

\section{Discussion}

In this article, we reviewed the information available to date about TA systems in clinical pathogens. TA systems are involved in some types of bacterial behavior, such as plasmid maintenance, biofilm formation, phase variation, virulence regulation, genetic competence, persister cells [75], regulation of the SOS response and bacterial defense against bacteriophages (abortive infection).

In relation to plasmid maintenance, most of the pathogens in the ESKAPE group contain plasmids with resistance genes carrying TA systems. In vancomycin-resistant strains of E. faecium and E. faecalis,

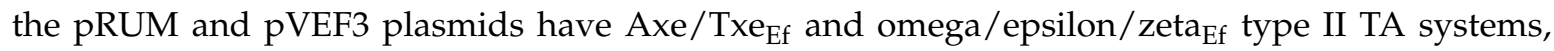
respectively $[22,23,80]$. On the other hand, the AbkB/AbkA type II TA system in plasmids carrying OXA 24/40 B-lactamase in A. baumannii clinical strains [38], as well as the Hok/Sok $\mathrm{Ec}_{\mathrm{c}}, \mathrm{SrnBC}_{\mathrm{V}} \mathrm{VagCD}_{\mathrm{Ec}}$,

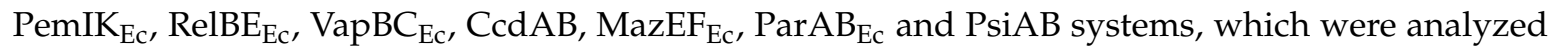
in ESBL-plasmids carrying CTX-M/TEM enzymes and isolated from E. coli strains, and finally, the ParAB $\mathrm{Pa}_{\mathrm{a}}$ TOX1/TOX2, T/AT1-2 systems have all been found in the pNOR-2000 plasmid encoding blaVIM-2 in clinical strains of P. aeruginosa [40]. Moreover, type II TA systems have been described in plasmids from environmental isolates, such as hyperthermophilic environments around hydrothermal vents located in the Atlantic, Pacific and Indian Oceans [138]. The plasmids can be ascribed to two subfamilies: pTN2-like and pEXT9a-like. Both plasmids encode TA systems of two different families: VapBC and RelBE. Moreover, other type II TA systems, such as VagCD, have been identified in IncF antibiotic-resistant and virulent plasmid pRSB225, isolated from an unknown bacterium released to the environment via the purified wastewater from a municipal sewage treatment plant [139]. Interestingly, modules of plasmid pRSB225 are associated with segments of different virulence plasmids harbored by entero-aggregative-hemorrhagic E. coli (EAHEC).

The relationship between biofilm formation and TA systems has been widely studied, particularly in E. coli [14,17,19,77] and P. aeruginosa [44]. In E. coli, several type II TA systems have been associated with biofilm formation, MqsR/MqsA, Hha/TomB, MazEF $E_{\text {c }}$, RelBEEc, YefM/YoeB $\mathrm{Ec}_{\mathrm{E}}$, DinJ/JafQ and GhoTS $_{\mathrm{Ec}}$, while only the HigBA $\mathrm{Pa}$ TA system has been associated with clinical strains of P. aeruginosa and biofilm formation. Nevertheless, further experimental studies may discover yet unknown relationships between TA systems in P. aeruginosa and biofilm formation persistence and virulence.

Other functions of TA systems include phase variation and genetic competence, although so far, only the YefM-YoeB ${ }_{S p}$ system in S. pneumoniae has been associated with these functions $[66,140]$. In 2012, Bukowski M. et al. analyzed the participation of the PemIK $\mathrm{Sa}_{\mathrm{Sa}}$ system located in the pCH91 plasmid of $S$. aureus in the global regulation of staphylococcal virulence by altering the translation of large gene pools [26].

Consistent with the role of TA systems and persistence, TA systems have been associated with

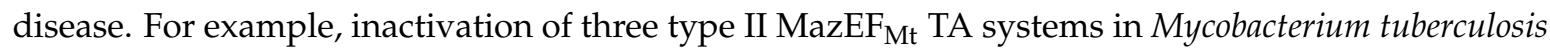
reduces its pathogenicity in macrophages and in the spleen and lungs of guinea pigs [141]. TA systems have also been found to affect the persistence of Salmonella typhimurium in macrophages in a mouse model of typhoid fever [142]. Furthermore, inactivation of Vap-type TA type II systems (VapBC-1 and VapXD TA loci) reduced virulence for non-typeable Haemophilus influenzae (NTHi) in a chinchilla model of otitis media [48], and as already discussed, inactivation of YoeB/YefM, Hha/TomB and PasT/PasI type II TA systems proved important for uropathogenic E. coli infections of the bladder

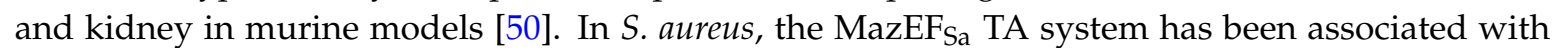
persistence [143] and virulence [144], while GhoTS $_{\mathrm{Ec}}$ and RelBE $\mathrm{Ec}_{\mathrm{C}}$ in E. coli $[6,14,145]$ and RelEB $\mathrm{Pa}$ and HigBA $_{\mathrm{Pa}}$ in P. aeruginosa $[44,59]$ have been associated with the same. The TisB/IstR and SymER TA type I systems have been associated with the regulation of the SOS response in E. coli [4,53,54]. Finally, 
type I, II, III and IV TA systems have been associated with the phage abortive infection system. Among these, we can highlight the following: Hok/Sok $\mathrm{Ec}_{\mathrm{c}}$ (type I TA system), which was the first TA system to be related to phage inhibition [146]; MazF/MazE Ec (type II TA system) [56]; ToxIN (type III TA system), found in E. coli strains [147,148]; AbiQ (type III TA system), studied in non-clinical strains, such as Lactococcus lactis and Lactobacillus pentosus KCA1 isolates [149,150]; and AbiEii (type IV TA system) in E. coli samples [151].

These functions or features have been associated with the phylogeny of the species in E. coli clinical strains, and the type II TA systems are also involved [152]. There is a potential link between chromosomal type II and E. coli phylogeny, with a small number found in group B2 (the main phylogenetic groups of E. coli clinical strains are A, B1, B2 and D).

In conclusion, further studies of these systems must be carried out in order to identify other TA pairs and to better define the role of these systems in bacterial virulence. For instance, the genetic diversity of $E$. coli is remarkably high, with a core genome (common to all strains) of approximately 2200 genes, while the accessory genome is much larger, comprising around 13,000 genes, many of which may be involved in bacterial virulence [153]. We hypothesize that some of these encode TA pairs that may be very important during infections. Given the importance of TA systems for the survival of pathogenic bacteria and infections, we propose that these systems could be exploited as novel targets for developing new anti-infectious treatments. This is an urgent need considering the accelerated rate of acquisition of multidrug resistance by intra-nosocomial strains, especially as their inactivation may lead to simultaneous decreases in infectivity, biofilm formation, resistance to stress and antibiotic persistence. In addition, as TA genes are absent in mammalian hosts, anti-TA drugs may be highly specific. Nevertheless, one possible drawback to the effectivity of these types of therapy is the high abundance of these systems in the genome, so that it would be necessary to develop broad spectrum anti-TA, or to simultaneously target several systems, or target those potentially controlling the expression of other TA systems. Another drawback is that it is not sufficient to simply inactivate antitoxins to activate toxins, as this would lead to an increase in persister cells because activation of a toxic protein produces persisters [154]; hence, the toxins would have to be inactivated by the new pharmaceuticals. Some side effects of these treatments may be generated due to inactivation of TA systems of bacterial species belonging to the normal microbiota. Encouraging further basic research on TA systems in different bacteria may provide valuable information for future therapeutic alternatives.

Acknowledgments: This work was funded by grants PI13/02390, awarded to María Tomas, the integrated National Plan for Scientific Research, Development and Technological Innovation 2008-2011 and 2013-2016, by the ISCIII-General Subdirection of Assessment and Promotion of the Research-European Regional Development Fund (FEDER) "A way of making Europe" and also by the Spanish Network for the Research in Infectious Diseases (REIPI RD12/0015) and by the Spanish Ministry of Health. María Tomas was financially supported by the Miguel Servet II Programme (SERGAS and ISCIII). Rodolfo García-Contreras is supported by the SEP-CONACyT Grant 152794 and by the UNAM-PAPIIT Grant IA201116. Thomas Wood was supported by the Army Research Office (W911NF-14-1-0279) and is Professor of the Biotechnology Endowed Chair at Pennsylvania State University.

Author Contributions: The chapters of this review were performed following this structure: Enterococcus spp and M. tuberculosis by L.F.-G. and M.L.; S. aureus by L.B. and G.B.; E. coli by R.G.-C.; P. aeruginosa by T.W., and finally, A. baumannii as well as abstract, introduction and discussion by M.T.

Conflicts of Interest: The authors declare no conflict of interest.

\section{References}

1. Makarova, K.S.; Wolf, Y.I.; Koonin, E.V. Comprehensive comparative-genomic analysis of type 2 toxin-antitoxin systems and related mobile stress response systems in prokaryotes. Biol. Direct. 2009, 4. [CrossRef] [PubMed]

2. Yamaguchi, Y.; Park, J.H.; Inouye, M. Toxin-antitoxin systems in bacteria and archaea. Annu. Rev. Genet. 2011, 45, 61-79. [CrossRef] [PubMed]

3. Mutschler, H.; Gebhardt, M.; Shoeman, R.L.; Meinhart, A. A novel mechanism of programmed cell death in bacteria by toxin-antitoxin systems corrupts peptidoglycan synthesis. PLoS Biol. 2011, 9. [CrossRef] [PubMed] 
4. Unoson, C.; Wagner, E.G. A small SOS-induced toxin is targeted against the inner membrane in Escherichia coli. Mol. Microbiol. 2008, 70, 258-270. [CrossRef] [PubMed]

5. Leplae, R.; Geeraerts, D.; Hallez, R.; Guglielmini, J.; Drèze, P.; Van Melderen, L. Diversity of bacterial type II toxin-antitoxin systems: a comprehensive search and functional analysis of novel families. Nucleic Acids Res. 2011, 39, 5513-5525. [CrossRef] [PubMed]

6. Gerdes, K.; Rasmussen, P.B.; Molin, S. Unique type of plasmid maintenance function: postsegregational killing of plasmid-free cells. Proc. Natl. Acad. Sci. USA 1986, 83, 3116-3120. [CrossRef] [PubMed]

7. Van Melderen, L.; Saavedra De Bast, M. Bacterial toxin-antitoxin systems: more than selfish entities? PLoS Genet. 2009, 5. [CrossRef] [PubMed]

8. Mochizuki, A.; Yahara, K.; Kobayashi, I.; Iwasa, Y. Genetic addiction: selfish gene's strategy for symbiosis in the genome. Genetics. 2006, 172, 1309-1323. [CrossRef] [PubMed]

9. Van Melderen, L. Toxin-antitoxin systems: why so many, what for? Curr. Opin. Microbiol. 2010, 13, 781-785. [CrossRef] [PubMed]

10. Lehnherr, H.; Maguin, E.; Jafri, S.; Yarmolinsky, M.B. Plasmid addiction genes of bacteriophage P1: doc, which causes cell death on curing of prophage, and phd, which prevents host death when prophage is retained. J. Mol. Biol. 1993, 233, 414-428. [CrossRef] [PubMed]

11. Ramage, H.R.; Connolly, L.E.; Cox, J.S. Comprehensive functional analysis of Mycobacterium tuberculosis toxin-antitoxin systems: implications for pathogenesis, stress responses, and evolution. PLoS Genet. 2009, 5. [CrossRef] [PubMed]

12. Yamaguchi, Y.; Inouye, M. mRNA interferases, sequence-specific endoribonucleases from the toxin-antitoxin systems. Prog. Mol. Biol. Transl. Sci. 2009, 85, 467-500.

13. Schuster, C.F.; Bertram, R. Toxin-antitoxin systems are ubiquitous and versatile modulators of prokaryotic cell fate. FEMS Microbiol. Lett. 2013, 340, 73-85. [CrossRef] [PubMed]

14. Wang, X.; Lord, D.M.; Cheng, H.Y.; Osbourne, D.O.; Hong, S.H.; Sanchez-Torres, V.; Quiroga, C.; Zheng, K.; Herrmann, T.; Peti, W.; et al. A new type V toxin-antitoxin system where mRNA for toxin GhoT is cleaved by antitoxin GhoS. Nat. Chem. Biol. 2012, 8, 855-861. [CrossRef] [PubMed]

15. Fair, R.J.; Tor, Y. Antibiotics and bacterial resistance in the 21st century. Perspect. Medicin. Chem. 2014, 6, 25-64. [PubMed]

16. Pendleton, J.N.; Gorman, S.P.; Gilmore, B.F. Clinical relevance of the ESKAPE pathogens. Expert Rev. Anti Infect. Ther. 2013, 11, 297-308. [CrossRef] [PubMed]

17. Kim, Y.; Wang, X.; Ma, Q.; Zhang, X.S.; Wood, T.K. Toxin-antitoxin systems in Escherichia coli influence biofilm formation through YjgK (TabA) and fimbriae. J. Bacteriol. 2009, 191, 1258-1267. [CrossRef] [PubMed]

18. Gerdes, K.; Maisonneuve, E. Bacterial persistence and toxin-antitoxin loci. Annu. Rev. Microbiol. 2012, 66, 103-123. [CrossRef] [PubMed]

19. Kolodkin-Gal, I.; Verdiger, R.; Shlosberg-Fedida, A.; Engelberg-Kulka, H. A differential effect of E. coli toxin-antitoxin systems on cell death in liquid media and biofilm formation. PLoS ONE 2009, 4. [CrossRef] [PubMed]

20. Brantl, S. Bacterial type I toxin-antitoxin systems. RNA Biol. 2012, 9, 1488-1490. [CrossRef] [PubMed]

21. Patel, S.; Weaver, K.E. Addiction toxin Fst has unique effects on chromosome segregation and cell division in Enterococcus faecalis and Bacillus subtilis. J. Bacteriol. 2006, 188, 5374-5384. [CrossRef] [PubMed]

22. Halvorsen, E.M.; Williams, J.J.; Bhimani, A.J.; Billings, E.A.; Hergenrother, P.J. Txe, an endoribonuclease of the enterococcal Axe-Txe toxin-antitoxin system, cleaves mRNA and inhibits protein synthesis. Microbiology 2011, 157, 387-397. [CrossRef] [PubMed]

23. Sletvold, H.; Johnsen, P.J.; Hamre, I.; Simonsen, G.S.; Sundsfjord, A.; Nielsen, K.M. Complete sequence of Enterococcus faecium $\mathrm{pVEF} 3$ and the detection of an omega-epsilon-zeta toxin-antitoxin module and an $\mathrm{ABC}$ transporter. Plasmid 2008, 60, 75-85. [CrossRef] [PubMed]

24. Rosvoll, T.C.; Pedersen, T.; Sletvold, H.; Johnsen, P.J.; Sollid, J.E.; Simonsen, G.S.; Jensen, L.B.; Nielsen, K.M.; Sundsfjord, A. PCR-based plasmid typing in Enterococcus faecium strains reveals widely distributed pRE25-, pRUM-, pIP501- and pHTbeta-related replicons associated with glycopeptide resistance and stabilizing toxin-antitoxin systems. FEMS Immunol. Med. Microbiol. 2010, 58, 254-268. [CrossRef] [PubMed]

25. Soheili, S.; Ghafourian, S.; Sekawi, Z.; Neela, V.K.; Sadeghifard, N.; Taherikalani, M.; Khosravi, A.; Ramli, R.; Hamat, R.A. The mazEF toxin-antitoxin system as an attractive target in clinical isolates of Enterococcus faecium and Enterococcus faecalis. Drug Des. Devel. Ther. 2015, 9, 2553-2561. [PubMed] 
26. Bukowski, M.; Lyzen, R.; Helbin, W.M.; Bonar, E.; Szalewska-Palasz, A.; Wegrzyn, G.; Dubin, G.; Dubin, A.; Wladyka, B. A regulatory role for Staphylococcus aureus toxin-antitoxin system PemIKSa. Nat. Commun. 2013, 4. [CrossRef] [PubMed]

27. Pinel-Marie, M.L.; Brielle, R.; Felden, B. Dual toxic-peptide-coding Staphylococcus aureus RNA under antisense regulation targets host cells and bacterial rivals unequally. Cell. Rep. 2014, 7, 424-435. [CrossRef] [PubMed]

28. Schuster, C.F.; Bertram, R. Toxin-Antitoxin Systems of Staphylococcus aureus. Toxins (Basel) 2016, 8. [CrossRef] [PubMed]

29. Sayed, N.; Nonin-Lecomte, S.; Réty, S.; Felden, B. Functional and structural insights of a Staphylococcus aureus apoptotic-like membrane peptide from a toxin-antitoxin module. J. Biol. Chem. 2012, 287, 43454-43463. [CrossRef] [PubMed]

30. Donegan, N.P.; Cheung, A.L. Regulation of the mazEF toxin-antitoxin module in Staphylococcus aureus and its impact on sigB expression. J. Bacteriol. 2009, 191, 2795-2805. [CrossRef] [PubMed]

31. Schuster, C.F.; Mechler, L.; Nolle, N.; Krismer, B.; Zelder, M.E.; Götz, F.; Bertram, R. The MazEF Toxin-Antitoxin System Alters the $\beta$-Lactam Susceptibility of Staphylococcus aureus. PLoS ONE 2015, 10. [CrossRef] [PubMed]

32. Fu, Z.; Tamber, S.; Memmi, G.; Donegan, N.P.; Cheung, A.L. Overexpression of MazFsa in Staphylococcus aureus induces bacteriostasis by selectively targeting mRNAs for cleavage. J. Bacteriol. 2009, 191, 2051-2059. [CrossRef] [PubMed]

33. Yoshizumi, S.; Zhang, Y.; Yamaguchi, Y.; Chen, L.; Kreiswirth, B.N.; Inouye, M. Staphylococcus aureus YoeB homologues inhibit translation initiation. J. Bacteriol. 2009, 191, 5868-5872. [CrossRef] [PubMed]

34. Larson, A.S.; Hergenrother, P.J. Light activation of Staphylococcus aureus toxin YoeBSa1 reveals guanosine-specific endoribonuclease activity. Biochemistry 2014, 53, 188-201. [CrossRef] [PubMed]

35. Wei, Y.Q.; Bi, D.X.; Wei, D.Q.; Ou, H.Y. Prediction of Type II Toxin-Antitoxin Loci in Klebsiella pneumoniae Genome Sequences. Interdiscip. Sci. 2016, 8, 143-149. [CrossRef] [PubMed]

36. Tashiro, Y.; Kawata, K.; Taniuchi, A.; Kakinuma, K.; May, T.; Okabe, S. RelE-mediated dormancy is enhanced at high cell density in Escherichia coli. J. Bacteriol. 2012, 194, 1169-1176. [CrossRef] [PubMed]

37. Ghafourian, S.; Good, L.; Sekawi, Z.; Hamat, R.A.; Soheili, S.; Sadeghifard, N.; Neela, V. The mazEF toxin-antitoxin system as a novel antibacterial target in Acinetobacter baumannii. Mem. Inst. Oswaldo Cruz. 2014, 109, 502-505. [CrossRef] [PubMed]

38. Mosqueda, N.; Gato, E.; Roca, I.; López, M.; de Alegría, C.R.; Fernández Cuenca, F.; Martínez-Martínez, L.; Pachón, J.; Cisneros, J.M.; Rodríguez-Baño, J. Characterization of plasmids carrying the blaOXA-24/40 carbapenemase gene and the genes encoding the AbkA/AbkB proteins of a toxin/antitoxin system. J. Antimicrob. Chemother. 2014, 69, 2629-2633. [CrossRef] [PubMed]

39. Chan, K.G.; Atkinson, S.; Mathee, K.; Sam, C.K.; Chhabra, S.R.; Cámara, M.; Koh, C.L.; Williams, P. Characterization of $\mathrm{N}$-acylhomoserine lactone-degrading bacteria associated with the Zingiber officinale (ginger) rhizosphere: co-existence of quorum quenching and quorum sensing in Acinetobacter and Burkholderia. BMC Microbiol. 2011, 11. [CrossRef] [PubMed]

40. Bonnin, R.A.; Poirel, L.; Nordmann, P.; Eikmeyer, F.G.; Wibberg, D.; Pühler, A.; Schlüter, A. Complete sequence of broad-host-range plasmid pNOR-2000 harbouring the metallo- $\beta$-lactamase gene blaVIM- 2 from Pseudomonas aeruginosa. J. Antimicrob. Chemother. 2013, 68, 1060-1065. [CrossRef] [PubMed]

41. Tamman, H.; Ainelo, A.; Ainsaar, K.; Hõrak, R. A Moderate Toxin, GraT, Modulates Growth Rate and Stress Tolerance of Pseudomonas putida. J. Bacteriol. 2014, 196, 157-169. [CrossRef] [PubMed]

42. Williams, J.J.; Halvorsen, E.M.; Dwyer, E.M.; DiFazio, R.M.; Hergenrother, P.J. Toxin-antitoxin (TA) systems are prevalent and transcribed in clinical isolates of Pseudomonas aeruginosa and methicillin-resistant Staphylococcus aureus. FEMS Microbiol. Lett. 2011, 322, 41-50. [CrossRef] [PubMed]

43. Williams, J.J.; Halvorsen, E.M.; Dwyer, E.M.; DiFazio, R.M.; Hergenrother, P.J. Toxin-antitoxin (TA) systems are prevalent and transcribed in clinical isolates of Pseudomonas aeruginosa and methicillin-resistant Staphylococcus aureus. FEMS Microbiol. Lett. 2011, 322, 41-50. [CrossRef] [PubMed]

44. Wood, T.L.; Wood, T.K. The HigB/HigA toxin/antitoxin system of Pseudomonas aeruginosa influences the virulence factors pyochelin, pyocyanin, and biofilm formation. Microbiol. Open 2016, 5. [CrossRef] [PubMed]

45. Ainelo, A.; Tamman, H.; Leppik, M.; Remme, J.; Hõrak, R. The toxin GraT inhibits ribosome biogenesis. Mol. Microbiol. 2016, 100, 719-731. [CrossRef] [PubMed] 
46. Kim, Y.; Wood, T.K. Toxins Hha and CspD and small RNA regulator Hfq are involved in persister cell formation through MqsR in Escherichia coli. Biochem. Biophys. Res. Commun. 2010, 391, 209-213. [CrossRef] [PubMed]

47. Dörr, T.; Vulić, M.; Lewis, K. Ciprofloxacin causes persister formation by inducing the TisB toxin in Escherichia coli. PLoS Biol. 2010, 8, 8. [CrossRef] [PubMed]

48. Ren, D.; Walker, A.N.; Daines, D.A. Toxin-antitoxin loci vapBC-1 and vapXD contribute to survival and virulence in nontypeable Haemophilus influenzae. BMC Microbial. 2012, 12. [CrossRef] [PubMed]

49. Garcia-Contreras, R.; Zhang, X.S.; Kim, Y.; Wood, T.K. Protein translation and cell death: the role of rare tRNAs in biofilm formation and in activating dormant phage killer genes. PLoS ONE 2008, 3. [CrossRef] [PubMed]

50. Norton, J.P.; Mulvey, M.A. Toxin-Antitoxin Systems Are Important for Niche-Specific Colonization and Stress Resistance of Uropathogenic Escherichia coli. PLoS Pathog. 2012, 8. [CrossRef] [PubMed]

51. Wang, J.; Stephan, R.; Zurfluh, K.; Hächler, H.; Fanning, S. Characterization of the genetic environment of bla ESBL genes, integrons and toxin-antitoxin systems identified on large transferrable plasmids in multi-drug resistant Escherichia coli. Front. Microbiol. 2014, 5. [CrossRef]

52. Schaufler, K.; Wieler, L.H.; Semmler, T.; Ewers, C.; Guenther, S. ESBL-plasmids carrying toxin-antitoxin systems can be "cured" of wild-type Escherichia coli using a heat technique. Gut Pathog. 2013, 5. [CrossRef] [PubMed]

53. Vogel, J.; Argaman, L.; Wagner, E.G.; Altuvia, S. The small RNA IstR inhibits synthesis of an SOS-induced toxic peptide. Curr. Biol. 2004, 14, 2271-2276. [CrossRef] [PubMed]

54. Kawano, M.; Aravind, L.; Storz, G. An antisense RNA controls synthesis of an SOS-induced toxin evolved from an antitoxin. Mol. Microbiol. 2007, 64, 738-754. [CrossRef] [PubMed]

55. Engelberg-Kulka, H.; Hazan, R.; Amitai, S. mazEF: A chromosomal toxin-antitoxin module that triggers programmed cell death in bacteria. J. Cell. Sci. 2005, 118, 4327-4332. [CrossRef] [PubMed]

56. Hazan, R.; Engelberg-Kulka, H. Escherichia coli mazEF-mediated cell death as a defense mechanism that inhibits the spread of phage P1. Mol. Genet. Genomics. 2004, 272, 227-234. [CrossRef] [PubMed]

57. Christensen, S.K.; Pedersen, K.; Hansen, F.G.; Gerdes, K. Toxin-antitoxin loci as stress-response-elements: ChpAK/MazF and ChpBK cleave translated RNAs and are counteracted by tmRNA. J. Mol. Biol. 2003, 332, 809-819. [CrossRef]

58. Zhang, Y.; Zhang, J.; Hara, H.; Kato, I.; Inouye, M. Insights into the mRNA cleavage mechanism by MazF, an mRNA interferase. J. Biol. Chem. 2005, 280, 3143-3150. [CrossRef] [PubMed]

59. Pedersen, K.; Zavialov, A.V.; Pavlov, M.Y.; Elf, J.; Gerdes, K.; Ehrenberg, M. The bacterial toxin RelE displays codon-specific cleavage of mRNAs in the ribosomal A site. Cell 2003, 112, 131-140. [CrossRef]

60. Zhang, Y.; Inouye, M. The inhibitory mechanism of protein synthesis by YoeB, an Escherichia coli toxin. J. Biol. Chem. 2009, 284, 6627-6638. [CrossRef] [PubMed]

61. Wang, X.; Kim, Y.; Hong, S.H.; Ma, Q.; Brown, B.L.; Pu, M.; Tarone, A.M.; Benedik, M.J.; Peti, W.; Page, R.; et al. Antitoxin MqsA helps mediate the bacterial general stress response. Nat. Chem. Biol. 2011, 7, 359-366. [CrossRef] [PubMed]

62. Cheng, H.Y.; Soo, V.W.; Islam, S.; McAnulty, M.J.; Benedik, M.J.; Wood, T.K. Toxin GhoT of the GhoT/GhoS toxin/antitoxin system damages the cell membrane to reduce adenosine triphosphate and to reduce growth under stress. Environ. Microbiol. 2014, 16, 1741-1754. [CrossRef] [PubMed]

63. Van Acker, H.; Sass, A.; Dhondt, I.; Nelis, H.J.; Coenye, T. Involvement of toxin-antitoxin modules in Burkholderia cenocepacia biofilm persistence. Pathog. Dis. 2014, 71, 326-335. [CrossRef] [PubMed]

64. Butt, A.; Higman, V.A.; Williams, C.; mp, M.P.; Hemsley, C.M.; Harmer, N.; Titball, R.W. The HicA toxin from Burkholderia pseudomallei has a role in persister cell formation. Biochem. J. 2014, 459, 333-344. [CrossRef] [PubMed]

65. Kirkpatrick, B.; Reeves, D.S.; MacGowan, A.P. A review of the clinical presentation, laboratory features, antimicrobial therapy and outcome of 77 episodes of pneumococcal meningitis occurring in children and adults. J. Infect. 1994, 29, 171-182. [CrossRef]

66. Chan, W.T.; Nieto, C.; Harikrishna, J.A.; Khoo, S.K.; Othman, R.Y.; Espinosa, M.; Yeo, C.C. Genetic regulation of the yefM-yoeB toxin-antitoxin locus of Streptococcus pneumoniae. J. Bacteriol. 2011, 193, 4612-4625. [CrossRef] [PubMed] 
67. Mutschler, H.; Reinstein, J.; Meinhart, A. Assembly dynamics and stability of the pneumococcal epsilon zeta antitoxin toxin (PezAT) system from Streptococcus pneumoniae. J. Biol. Chem. 2010, 285, 21797-21806. [CrossRef] [PubMed]

68. Chan, W.T.; Moreno-Cordoba, I.; Yeo, C.C.; Espinosa, M. Toxin-antitoxin genes of the Gram-positive pathogen Streptococcus pneumoniae: so few and yet so many. Microbiol. Mol. Biol. Rev. 2012, 76, 773-791. [CrossRef] [PubMed]

69. Sala, A.; Bordes, P.; Genevaux, P. Multiple toxin-antitoxin systems in Mycobacterium tuberculosis. Toxins (Basel) 2014, 6, 1002-1020. [CrossRef] [PubMed]

70. Gupta, A. Killing activity and rescue function of genome-wide toxin-antitoxin loci of Mycobacterium tuberculosis. FEMS Microbiol. Lett. 2009, 290, 45-53. [CrossRef] [PubMed]

71. Smollett, K.L.; Fivian-Hughes, A.S.; Smith, J.E.; Chang, A.; Rao, T.; Davis, E.O. Experimental determination of translational start sites resolves uncertainties in genomic open reading frame predictions - application to Mycobacterium tuberculosis. Microbiol. 2009, 155, 186-197. [CrossRef] [PubMed]

72. Stewart, G.R.; Wernisch, L.; Stabler, R.; ngan, J.A.; Hinds, J.; Laing, K.G.; Young, D.B.; Butcher, P.D. Dissection of the heat-shock response in Mycobacterium tuberculosis using mutants and microarrays. Microbiol. 2002, 148, 3129-3138. [CrossRef] [PubMed]

73. Tailleux, L.; Waddell, S.J.; Pelizzola, M.; Mortellaro, A.; Withers, M.; Tanne, A.; Castagnoli, P.R.; Gicquel, B.; Stoker, N.G.; Butcher, P.D.; et al. Probing host pathogen cross-talk by transcriptional profiling of both Mycobacterium tuberculosis and infected human dendritic cells and macrophages. PLoS ONE 2008, 3. [CrossRef] [PubMed]

74. Huang, F.; He, Z.G. Characterization of an interplay between a Mycobacterium tuberculosis MazF homolog, Rv1495 and its sole DNA topoisomerase I. Nucleic Acids Res. 2010, 38, 8219-8230. [CrossRef] [PubMed]

75. Ghafourian, S.; Raftari, M.; Sadeghifard, N.; Sekawi, Z. Toxin-antitoxin Systems: Classification, Biological Function and Application in Biotechnology. Curr. Issues Mol. Biol. 2014, 16, 9-14. [PubMed]

76. Dy, R.L.; Richter, C.; Salmond, G.P.; Fineran, P.C. Remarkable Mechanisms in Microbes to Resist Phage Infections. Annu. Rev. Virol. 2014, 1, 307-331. [CrossRef] [PubMed]

77. Karimi, S.; Ghafourian, S.; Taheri Kalani, M.; Azizi Jalilian, F.; Hemati, S.; Sadeghifard, N. Association between toxin-antitoxin systems and biofilm formation. Jundishapur J. Microbiol. 2015, 8. [CrossRef] [PubMed]

78. Miller, W.R.; Munita, J.M.; Arias, C.A. Mechanisms of antibiotic resistance in enterococci. Expert Rev. Anti Infect. Ther. 2014, 12, 1221-1236. [CrossRef] [PubMed]

79. Weaver, K.E.; Reddy, S.G.; Brinkman, C.L.; Patel, S.; Bayles, K.W.; Endres, J.L. Identification and characterization of a family of toxin-antitoxin systems related to the Enterococcus faecalis plasmid pAD1 par addiction module. Microbiology 2009, 155, 2930-2940. [CrossRef] [PubMed]

80. Grady, R.; Hayes, F. Axe-Txe, a broad-spectrum proteic toxin-antitoxin system specified by a multidrug-resistant, clinical isolate of Enterococcus faecium. Mol. Microbiol. 2003, 47, 1419-1432. [CrossRef] [PubMed]

81. Goeders, N.; Van Melderen, L. Toxin-antitoxin systems as multilevel interaction systems. Toxins (Basel) 2014, 6, 304-324. [CrossRef] [PubMed]

82. Fozo, E.M.; Makarova, K.S.; Shabalina, S.A.; Yutin, N.; Koonin, E.V.; Storz, G. Abundance of type I toxin-antitoxin systems in bacteria: Searches for new candidates and discovery of novel families. Nucleic Acids Res. 2010, 38, 3743-3759. [CrossRef] [PubMed]

83. Zhu, L.; Inoue, K.; Yoshizumi, S.; Kobayashi, H.; Zhang, Y.; Ouyang, M.; Kato, F.; Sugai, M.; Inouye, M. Staphylococcus aureus MazF specifically cleaves a pentad sequence, UACAU, which is unusually abundant in the mRNA for pathogenic adhesive factor SraP. J. Bacteriol. 2009, 191, 3248-3255. [CrossRef] [PubMed]

84. Locke, J.B.; Rahawi, S.; Lamarre, J.; Mankin, A.S.; Shaw, K.J. Genetic environment and stability of cfr in methicillin-resistant Staphylococcus aureus CM05. Antimicrob. Agents Chemother. 2012, 56, 332-340. [CrossRef] [PubMed]

85. Dmowski, M.; Sitkiewicz, I.; Ceglowski, P. Characterization of a novel partition system encoded by the delta and omega genes from the streptococcal plasmid pSM19035. J. Bacteriol. 2006, 188, 4362-4372. [CrossRef] [PubMed] 
86. Khoo, S.K.; Loll, B.; Chan, W.T.; Shoeman, R.L.; Ngoo, L.; Yeo, C.C.; Meinhart, A. Molecular and structural characterization of the PezAT chromosomal toxin-antitoxin system of the human pathogen Streptococcus pneumoniae. J. Biol. Chem. 2007, 282, 19606-19618. [CrossRef] [PubMed]

87. Peleg, A.Y.; Seifert, H.; Paterson, D.L. Acinetobacter baumannii: Emergence of a successful pathogen. Clin. Microbiol. Rev. 2008, 21, 538-582. [CrossRef] [PubMed]

88. Chastre, J.; Trouillet, J.L. Problem pathogens (Pseudomonas aeruginosa and Acinetobacter). Semin. Respir. Infect. 2000, 15, 287-298. [CrossRef] [PubMed]

89. Smith, M.G.; Gianoulis, T.A.; Pukatzki, S.; Mekalanos, J.J.; Ornston, L.N.; Gerstein, M.; Snyder, M. New insights into Acinetobacter baumannii pathogenesis revealed by high-density pyrosequencing and transposon mutagenesis. Genes Dev. 2007, 21, 601-614. [CrossRef] [PubMed]

90. Jurenaite, M.; Markuckas, A.; Suziedeliene, E. Identification and characterization of type II toxin-antitoxin systems in the opportunistic pathogen Acinetobacter baumannii. J. Bacteriol. 2013, 195, 3165-3172. [CrossRef] [PubMed]

91. Lean, S.S.; Yeo, C.C.; Suhaili, Z.; Thong, K.L. Comparative Genomics of Two ST 195 Carbapenem-Resistant Acinetobacter baumannii with Different Susceptibility to Polymyxin Revealed Underlying Resistance Mechanism. Front. Microbiol. 2015, 6. [CrossRef]

92. Mace, C.; Seyer, D.; Chemani, C.; Cosette, P.; Di-Martino, P.; Guery, B.; Filloux, A.; Fontaine, M.; Molle, V.; Junter, G.A.; et al. Identification of biofilm-associated cluster (bac) in Pseudomonas aeruginosa involved in biofilm formation and virulence. PLoS ONE 2008, 3. [CrossRef] [PubMed]

93. Moker, N.; Dean, C.R.; Tao, J. Pseudomonas aeruginosa increases formation of multidrug-tolerant persister cells in response to quorum-sensing signaling molecules. J. Bacteriol. 2010, 192, 1946-1955. [CrossRef] [PubMed]

94. Ryder, C.; Byrd, M.; Wozniak, D.J. Role of polysaccharides in Pseudomonas aeruginosa biofilm development. Curr. Opin. Microbiol. 2007, 10, 644-648. [CrossRef] [PubMed]

95. Lewis, K. Multidrug tolerance of biofilms and persister cells. Curr. Top. Microbiol. Immunol. 2008, 322, 107-131. [PubMed]

96. Christensen-Dalsgaard, M.; Gerdes, K. Two higBA loci in the Vibrio cholerae superintegron encode mRNA cleaving enzymes and can stabilize plasmids. Mol. Microbiol. 2006, 62, 397-411. [CrossRef] [PubMed]

97. Budde, P.P.; Davis, B.M.; Yuan, J.; Waldor, M.K. Characterization of a higBA toxin-antitoxin locus in Vibrio cholerae. J. Bacteriol. 2007, 189, 491-500. [CrossRef] [PubMed]

98. Chan, W.T.; Moreno-Cordoba, I.; Yeo, C.C.; Espinosa, M. Toxin-Antitoxin Genes of the Gram-Positive Pathogen Streptococcus pneumoniae: So Few and Yet So Many. Microbiol. Mol. Biol. Rev. 2012, 76, 773-791. [CrossRef] [PubMed]

99. De la Cruz, M.A.; Zhao, W.D.; Farenc, C.; Gimenez, G.; Raoult, D.; Cambillau, C.; Gorvel, J.P.; Méresse, S. A toxin-antitoxin module of Salmonella promotes virulence in mice. PLoS Pathog. 2013, 9. [CrossRef] [PubMed]

100. Goulard, C.; Langrand, S.; Carniel, E.; Chauvaux, S. The Yersinia pestis chromosome encodes active addiction toxins. J. Bacteriol. 2010, 192, 3669-3677. [CrossRef] [PubMed]

101. Schuessler, D.L.; Cortes, T.; Fivian-Hughes, A.S.; ougheed, K.E.; Harvey, E.; Buxton, R.S.; Davis, E.O.; Young, D.B. Induced ectopic expression of HigB toxin in Mycobacterium tuberculosis results in growth inhibition, reduced abundance of a subset of mRNAs and cleavage of tmRNA. Mol. Microbiol. 2013, 90, 195-207. [PubMed]

102. Pandey, D.P.; Gerdes, K. Toxin-antitoxin loci are highly abundant in free-living but lost from host-associated prokaryotes. Nucleic Acids Res. 2005, 33, 966-976. [CrossRef] [PubMed]

103. Christensen-Dalsgaard, M.; Jorgensen, M.G.; Gerdes, K. Three new RelE-homologous mRNA interferases of Escherichia coli differentially induced by environmental stresses. Mol. Microbiol. 2010, 75, 333-348. [CrossRef] [PubMed]

104. Hurley, J.M.; Woychik, N.A. Bacterial Toxin HigB Associates with Ribosomes and Mediates Translation-dependent mRNA Cleavage at A-rich Sites. J. Biol. Chem. 2009, 284, 18605-18613. [CrossRef] [PubMed]

105. Mulcahy, L.R.; Burns, J.L.; Lory, S.; Lewis, K. Emergence of Pseudomonas aeruginosa Strains Producing High Levels of Persister Cells in Patients with Cystic Fibrosis. J. Bacteriol. 2010, 192, 6191-6199. [CrossRef] [PubMed] 
106. Kwan, B.W.; Valenta, J.A.; Benedik, M.J.; Wood, T.K. Arrested protein synthesis increases persister-like cell formation. Antimicrob. Agents Chemother. 2013, 57, 1468-1473. [CrossRef] [PubMed]

107. Lewis, K. Persister cells, dormancy and infectious disease. Nat. Rev. Microb. 2007, 5, 48-56. [CrossRef] [PubMed]

108. Wood, T.K. Combatting bacterial persister cells. Biotechnol. Bioeng. 2016, 113, 476-483. [CrossRef] [PubMed]

109. Wang, X.; Wood, T.K. Toxin-antitoxin systems influence biofilm and persister cell formation and the general stress response. Appl. Environ. Microbiol. 2011, 77, 5577-5583. [CrossRef] [PubMed]

110. Shah, D.; Zhang, Z.; Khodursky, A.; Kaldalu, N.; Kurg, K.; Lewis, K. Persisters: a distinct physiological state of E. coli. BMC Microbiol. 2006, 6. [CrossRef] [PubMed]

111. Keren, I.; Kaldalu, N.; Spoering, A.; Wang, Y.; Lewis, K. Persister cells and tolerance to antimicrobials. FEMS Microbiol. Lett. 2004, 230, 13-18. [CrossRef]

112. (CDC) CfDC. Isolation of E. coli O157:H7 from sporadic cases of hemorrhagic colitis-United States. MMWR Morb. Mortal. Wkly. Rep. 1982, 31, 580-585.

113. Hazan, R.; Sat, B.; Engelberg-Kulka, H. Escherichia coli mazEF-mediated cell death is triggered by various stressful conditions. J. Bacteriol. 2004, 186, 3663-3669. [CrossRef] [PubMed]

114. Ren, D.; Bedzyk, L.A.; Thomas, S.M.; Ye, R.W.; Wood, T.K. Gene expression in Escherichia coli biofilms. Appl. Microbiol. Biotechnol. 2004, 64, 515-524. [CrossRef] [PubMed]

115. Brown, B.L.; Grigoriu, S.; Kim, Y.; rruda, J.M.; Davenport, A.; Wood, T.K.; Peti, W.; Page, R. Three dimensional structure of the MqsR:MqsA complex: a novel TA pair comprised of a toxin homologous to RelE and an antitoxin with unique properties. PLoS Pathog. 2009, 5. [CrossRef] [PubMed]

116. Brown, B.L.; Wood, T.K.; Peti, W.; Page, R. Structure of the Escherichia coli antitoxin MqsA (YgiT/b3021) bound to its gene promoter reveals extensive domain rearrangements and the specificity of transcriptional regulation. J. Biol. Chem. 2011, 286, 2285-2296. [CrossRef] [PubMed]

117. Wang, X.; Lord, D.M.; Hong, S.H.; Peti, W.; Benedik, M.J.; Page, R.; Wood, T.K. Type II toxin/antitoxin MqsR/MqsA controls type V toxin/antitoxin GhoT/GhoS. Environ. Microbiol. 2013, 15, 1734-1744. [CrossRef] [PubMed]

118. Kwan, B.W.; Lord, D.M.; Peti, W.; Page, R.; Benedik, M.J.; Wood, T.K. The MqsR/MqsA toxin/antitoxin system protects Escherichia coli during bile acid stress. Environ. Microbiol. 2015, 17, 3168-3181. [CrossRef] [PubMed]

119. Yamaguchi, Y.; Park, J.H.; Inouye, M. MqsR, a crucial regulator for quorum sensing and biofilm formation, is a GCU-specific mRNA interferase in Escherichia coli. J. Biol. Chem. 2009, 284, 28746-28753. [CrossRef] [PubMed]

120. Lipuma, J.J. Update on the Burkholderia cepacia complex. Curr. Opin. Pulm. Med. 2005, 11, 528-533. [CrossRef] [PubMed]

121. Mahenthiralingam, E.; Urban, T.A.; Goldberg, J.B. The multifarious, multireplicon Burkholderia cepacia complex. Nat. Rev. Microbiol. 2005, 3, 144-156. [CrossRef] [PubMed]

122. Currie, B.J.; Fisher, D.A.; Anstey, N.M.; Jacups, S.P. Melioidosis: acute and chronic disease, relapse and re-activation. Trans. R. Soc. Trop. Med. Hyg. 2000, 94, 301-304. [CrossRef]

123. Agnoli, K.; Frauenknecht, C.; Freitag, R.; hwager, S.; Jenul, C.; Vergunst, A.; Carlier, A.; Eberl, L. The third replicon of members of the Burkholderia cepacia Complex, plasmid pC3, plays a role in stress tolerance. Appl. Environ. Microbiol. 2014, 80, 1340-1348. [CrossRef] [PubMed]

124. Nieto, C.; Cherny, I.; Khoo, S.K.; e Lacoba, M.G.; Chan, W.T.; Yeo, C.C.; Gazit, E.; Espinosa, M. The yefM-yoeB toxin-antitoxin systems of Escherichia coli and Streptococcus pneumoniae: Functional and structural correlation. J. Bacteriol. 2007, 189, 1266-1278. [CrossRef] [PubMed]

125. Behnke, D.; Malke, H.; Hartmann, M.; Walter, F. Post-transformational rearrangement of an in vitro reconstructed group-A streptococcal erythromycin resistance plasmid. Plasmid 1979, 2, 605-616. [CrossRef]

126. Ceglowski, P.; Boitsov, A.; Karamyan, N.; Chai, S.; Alonso, J.C. Characterization of the effectors required for stable inheritance of Streptococcus pyogenes pSM19035-derived plasmids in Bacillus subtilis. Mol. Gen. Genet. 1993, 241, 579-585. [CrossRef] [PubMed]

127. Nieto, C.; Sadowy, E.; de la Campa, A.G.; Hryniewicz, W.; Espinosa, M. The relBE2Spn toxin-antitoxin system of Streptococcus pneumoniae: Role in antibiotic tolerance and functional conservation in clinical isolates. PLoS ONE 2010, 5. [CrossRef] [PubMed] 
128. Chan, W.T.; Yeo, C.C.; Sadowy, E.; Espinosa, M. Functional validation of putative toxin-antitoxin genes from the Gram-positive pathogen Streptococcus pneumoniae: phd-doc is the fourth bona-fide operon. Front. Microbiol. 2014, 5. [CrossRef] [PubMed]

129. Tuberculosis. Available online: http://www.who.int/mediacentre/factsheets/fs104/en/ (accessed on 10 June 2016).

130. Han, J.S.; Lee, J.J.; Anandan, T.; Sripathi, S.; Jahng, W.J.; Lee, S.H.; Suh, J.W.; Kang, C.M. Characterization of a chromosomal toxin-antitoxin, Rv1102c-Rv1103c system in Mycobacterium tuberculosis. Biochem. Biophys. Res. Commun. 2010, 400, 293-298. [CrossRef] [PubMed]

131. Singh, R.; Barry, C.E.; Boshoff, H.I. The three RelE homologs of Mycobacterium tuberculosis have individual, drug-specific effects on bacterial antibiotic tolerance. J. Bacteriol. 2010, 192, 1279-1291. [CrossRef] [PubMed]

132. Korch, S.B.; Contreras, H.; Clark-Curtiss, J.E. Three Mycobacterium tuberculosis Rel toxin-antitoxin modules inhibit mycobacterial growth and are expressed in infected human macrophages. J. Bacteriol. 2009, 191, 1618-1630. [CrossRef] [PubMed]

133. Keren, I.; Minami, S.; Rubin, E.; Lewis, K. Characterization and transcriptome analysis of Mycobacterium tuberculosis persisters. MBio 2011, 2. [CrossRef] [PubMed]

134. Stinear, T.P.; Seemann, T.; Harrison, P.F.; Jenkin, G.A.; Davies, J.K.; Johnson, P.D.; Abdellah, Z.; Arrowsmith, C.; Chillingworth, T.; Churcher, C.; et al. Insights from the complete genome sequence of Mycobacterium marinum on the evolution of Mycobacterium tuberculosis. Genome Res. 2008, 18, 729-741. [CrossRef] [PubMed]

135. Zhu, L.; Sharp, J.D.; Kobayashi, H.; Woychik, N.A.; Inouye, M. Noncognate Mycobacterium tuberculosis toxin-antitoxins can physically and functionally interact. J. Biol. Chem. 2010, 285, 39732-39738. [CrossRef] [PubMed]

136. Lee, I.G.; Lee, S.J.; Chae, S.; Lee, K.Y.; Kim, J.H.; Lee, B.J. Structural and functional studies of the Mycobacterium tuberculosis VapBC30 toxin-antitoxin system: implications for the design of novel antimicrobial peptides. Nucleic Acids Res. 2015, 43, 7624-7637. [CrossRef] [PubMed]

137. Albrethsen, J.; Agner, J.; Piersma, S.R.; Højrup, P.; Pham, T.V.; Weldingh, K.; Jimenez, C.R.; Andersen, P.; Rosenkrands, I. Proteomic profiling of Mycobacterium tuberculosis identifies nutrient-starvation-responsive toxin-antitoxin systems. Mol. Cell. Proteom. 2013, 12, 1180-1191. [CrossRef] [PubMed]

138. Krupovic, M.; Gonnet, M.; Hania, W.B.; Forterre, P.; Erauso, G. Insights into dynamics of mobile genetic elements in hyperthermophilic environments from five new Thermococcus plasmids. PLoS ONE 2013, 8. [CrossRef] [PubMed]

139. Wibberg, D.; Szczepanowski, R.; Eikmeyer, F.; Puhler, A.; Schluter, A. The IncF plasmid pRSB225 isolated from a municipal wastewater treatment plant's on-site preflooder combining antibiotic resistance and putative virulence functions is highly related to virulence plasmids identified in pathogenic E. coli isolates. Plasmid 2013, 69, 127-137. [CrossRef] [PubMed]

140. Saluja, S.K.; Weiser, J.N. The genetic basis of colony opacity in Streptococcus pneumoniae: Evidence for the effect of box elements on the frequency of phenotypic variation. Mol. Microbiol. 1995, 16, 215-227. [CrossRef] [PubMed]

141. Tiwari, P.; Arora, G.; Singh, M.; Kidwai, S.; Narayan, O.P.; Singh, R. MazF ribonucleases promote Mycobacterium tuberculosis drug tolerance and virulence in guinea pigs. Nat. Commun. 2015, 6. [CrossRef] [PubMed]

142. Helaine, S.; Cheverton, A.M.; Watson, K.G.; Faure, L.M.; Matthews, S.A.; Holden, D.W. Internalization of Salmonella by Macrophages Induces Formation of Nonreplicating Persisters. Science 2014, 343, $204-208$. [CrossRef] [PubMed]

143. Proctor, R.A.; Kriegeskorte, A.; Kahl, B.C.; Becker, K.; Löffler, B.; Peters, G. Staphylococcus aureus Small Colony Variants (SCVs): A road map for the metabolic pathways involved in persistent infections. Front. Cell. Infect. Microbiol. 2014, 4, 99. [PubMed]

144. Conlon, B.P. Staphylococcus aureus chronic and relapsing infections: Evidence of a role for persister cells: An investigation of persister cells, their formation and their role in S. aureus disease. Bioessays 2014, 36, 991-996. [CrossRef] [PubMed]

145. Gelens, L.; Hill, L.; Vandervelde, A.; Danckaert, J.; Loris, R. A general model for toxin-antitoxin module dynamics can explain persister cell formation in E. coli. PLoS Comput. Biol. 2013, 9. [CrossRef] [PubMed] 
146. Pecota, D.C.; Wood, T.K. Exclusion of T4 Phage by the hok/sok Killer Locus from Plasmid R1. J. Bacteriol. 1996, 178, 2044-2050. [PubMed]

147. Fineran, P.C.; Blower, T.R.; Foulds, I.J.; Humphreys, D.P.; Lilley, K.S.; Salmond, G.P. The phage abortive infection system, ToxIN, functions as a protein-RNA toxin-antitoxin pair. Proc. Natl. Acad. Sci. USA 2009, 106, 894-899. [CrossRef] [PubMed]

148. Blower, T.R.; Short, F.L.; Rao, F.; guchi, K.; Pei, X.Y.; Fineran, P.C.; Luisi, B.F.; Salmond, G.P. Identification and classification of bacterial Type III toxin-antitoxin systems encoded in chromosomal and plasmid genomes. Nucleic Acids Res. 2012, 40, 6158-6173. [CrossRef] [PubMed]

149. Samson, J.E.; Spinelli, S.; Cambillau, C.; Moineau, S. Structure and activity of AbiQ, a lactococcal endoribonuclease belonging to the type III toxin-antitoxin system. Mol. Microbiol. 2013, 87, 756-768. [CrossRef] [PubMed]

150. Anukam, K.C.; Macklaim, J.M.; Gloor, G.B.; Reid, G.; Boekhorst, J.; Renckens, B.; van Hijum, S.A.; Siezen, R.J. Genome sequence of Lactobacillus pentosus KCA1: Vaginal isolate from a healthy premenopausal woman. PLoS ONE 2013, 8. [CrossRef] [PubMed]

151. Dy, R.L.; Przybilski, R.; Semeijn, K.; Salmond, G.P.; Fineran, P.C. A widespread bacteriophage abortive infection system functions through a Type IV toxin-antitoxin mechanism. Nucleic Acids Res. 2014, 42, 4590-4605. [CrossRef] [PubMed]

152. Fiedoruk, K.; Daniluk, T.; Swiecicka, I.; Sciepuk, M.; Leszczynska, K. Type II toxin-antitoxin systems are unevenly distributed among Escherichia coli phylogroups. Microbiology 2015, 161, 158-167. [CrossRef] [PubMed]

153. Rasko, D.A.; Rosovitz, M.J.; Myers, G.S.; Mongodin, E.F.; Fricke, W.F.; Gajer, P.; Crabtree, J.; Sebaihia, M.; Thomson, N.R.; Chaudhuri, R.; et al. The pangenome structure of Escherichia coli: Comparative genomic analysis of E. coli commensal and pathogenic isolates. J. Bacteriol. 2008, 190, 6881-6893. [CrossRef] [PubMed]

154. Chowdhury, N.; Kwan, B.W.; Wood, T.K. Persistence Increases in the Absence of the Alarmone Guanosine Tetraphosphate by Reducing Cell Growth. Sci. Rep. 2016, 6. [CrossRef] [PubMed]

(C) 2016 by the authors; licensee MDPI, Basel, Switzerland. This article is an open access article distributed under the terms and conditions of the Creative Commons Attribution (CC-BY) license (http://creativecommons.org/licenses/by/4.0/). 